http://dx.doi.org/10.18232/20073496.1185

Artigos

\title{
A questão racial e os limites do desenvolvimento econômico-social brasileiro: uma perspectiva crítica
}

\section{The racial issue and the limits of Brazilian economic and social development: a critical perspective}

\author{
Carlos A. Guimarães ${ }^{1,}$ * (DD 0000-0001-6718-7656 \\ Leonardo Carnut ${ }^{2}$ (D) 0000-0001-6415-6977 \\ Áquilas Mendes ${ }^{1,3}$ (D) 0000-0002-5632-4333
}

\footnotetext{
${ }^{1}$ Pontifícia Universidade Católica de São Paulo, São Paulo, Brasil.

${ }^{2}$ Universidade Federal de São Paulo, São Paulo, Brasil.

${ }^{3}$ Faculdade de Saúde Pública, Universidade de São Paulo, São Paulo, Brasil.
}

*Correspondencia: carlosdg.contato@outlook.com

Resumo. O objetivo é analisar a questão racial brasileira como obstáculo histórico ao desenvolvimento econômico-social do país, a partir de uma perspectiva crítica marxista. Considera-se que as relações sociais são moldadas não somente pelo regime de classes como também pelo mito da democracia racial como ferramenta de uma velada segregação - que, como tal, também se mostra uma densa barreira ao fortalecimento de um proletariado sólido-. A metodologia utilizada consistiu em defrontar a argumentação das clássicas teses de Florestan Fernandes e Octávio Ianni com artigos científicos mais recentes, levantando convergências e divergências, para, a partir dos dados levantados, demonstrar que a conscientização acerca da questão racial é condição sine qua non para a legitimação e o fortalecimento do proletariado.

Palavras-chave: marxismo; pensamento econômico; economia heterodoxa; história do pensamento econômico.

CÓMO CITAR: Guimarães, C. A., Carnut, L. e Mendes, A. (2022). A questão racial e os limites do desenvolvimento econômicosocial brasileiro: uma perspectiva crítica. América Latina en la Historia Económica, 29(1), 1-33. DOI: 10.18232/20073496.1185 
Abstract. The objective is to analyze the Brazilian racial issue as a historical obstacle to the country's economic and social development, from a critical Marxist perspective. It is considered that social relations are shaped not only by the class regime but also by the myth of racial democracy as a tool of veiled segregation -which, as such, also proves to be dense barrier to the strengthening of a solid proletariat-. The methodology used consisted of confronting the arguments of the classic theses of Florestan Fernandes and Octávio Ianni with more recent scientific articles, raising convergences and divergences, in order to demonstrate, from the data collected, that awareness about the racial issue is a sine qua non condition for legitimation. and the strengthening of the proletariat.

Key words: marxism; economic thought; heterodox economics; history of economic thought.

JEL: B51; B3; B5; B24; N00; N96.

Recebido: 12 de março de 2020.

Aceito: 9 de abril de 2021.

Publicado: 22 de novembro de 2021.

\section{INTRODUÇÃO}

O racismo representa uma sólida e subestimada barreira ao desenvolvimento econômico e social do país. Ainda, no século xxi, o racismo se recria em suas formas e serve como ferramenta de manutenção para um sistema que promove privilégios a uma minoria às custas de uma grande parcela da população sob desvantagem social. A maioria prejudicada por esse sistema racista é composta por pessoas negras e não negras -o que, mesmo comportando diferentes graus de desigualdade, torna esse problema algo generalizado.

No Brasil, o mito da 'democracia racial' ${ }^{1}$ enraizado na estrutura social do país consolidou uma aceitação social do ato racista. Contudo, a compreensão do que é de fato o racismo é essencial para que se possa desconstruí-lo gradativamente e, por fim, eliminar esta espessa barreira ao desenvolvimento econômico. A identificação do 'pensamento patrono'; a crítica aos costumes da casa-grande que se espelham até os dias de hoje nas relações sociais e a delimitação do clamor controlador de uma entidade autoritária para o estabelecimento da sensação de paz são, na desconstrução desses costumes, os elementos que tornariam possível a promoção de uma concreta revolução e de um efetivo desenvolvimento econômico-social.

Em momentos de radicalismo e polarização política cada dia mais se normaliza a barbárie. Para mensurar o racismo como uma das formas de manutenção do capitalismo é necessário, antes, reconhecer suas formas de manifestação nas estruturas do senso comum. Observar o contraste existente, entre pessoas negras e não negras, desde as relações sociais às oportunidades do mercado de trabalho é o cerne deste trabalho. Não se trata de pensar somente na (necessária) inclusão da população negra, e sim, pensar em melhores oportunidades para todos.

${ }^{1}$ Diante de várias denominações do termo "democracia racial”, utilizamos a abordagem de Sales Jr (2006a) quando argumenta que a "democracia racial” aporta uma contradição nos seus termos. Segundo esse autor é somente possível existir uma democracia sem que ela seja "racial". A verdadeira democracia é anti-racialista, ou seja, não se refere a "raças" ou a "relações raciais", constituindo-se por um ato de exclusão dessas últimas. Por sua vez, a verdadeira democracia racial só pode estar presente se enfrentar as relações raciais e resolver publicamente os conflitos raciais. Para uma abordagem mais completa, ver Sales Jr (2006b), cap. 4. 
Assim, este estudo tem como objetivo analisar a questão racial brasileira como obstáculo histórico ao desenvolvimento econômico-social do país, a partir de uma perspectiva crítica marxista. Para tanto, este estudo está estruturado em três partes. A primeira apresenta o desenvolvimento do Brasil fundamentado nas teses relacionadas às questões étnico-raciais em dois pensadores clássicos da formação social crítica marxista brasileira: Octávio Ianni e Florestan Fernandes. A segunda parte, de forma sucinta, descreve o percurso metodológico desta revisão sistematizada da literatura, identificando os artigos científicos dos periódicos nacionais que descrevem contemporaneamente a questão racial e sua relação com o desenvolvimento econômico no Brasil. A terceira parte analisa criticamente as convergências e divergências entre os artigos científicos e as obras dos autores Ianni e Fernandes sobre os argumentos relacionados à questão racial e o desenvolvimento, apontando os limites a serem superados.

\section{A QUESTÃo RAGIAL NOS 'TRÊS LIMITES' PARA O DESENVOLVIMENTO ECONÔMICO-SOCIAL BRASILEIRO em Octávio Ianni e Florestan Fernandes}

Primeiro limite: questão racial na ausência de identidade

Diante de um momento de ruptura, em que se faz necessário repensar o presente buscando por raízes na formação desse modelo de sociedade, o Brasil esbarra no fato de não ter uma identidade representativa em relação ao seu povo -visto que os maiores acontecimentos de suas histórias foram determinados de 'cima' para 'baixo'. Como observa Ianni (1966) o atraso do Brasil começa a se estruturar em 1822, quando -apesar de muitas lutas, campanhas e revoltas- o país não consegue se adequar ao ritmo das mudanças estruturais que ocorrem no capitalismo europeu, tendo seus objetivos republicanos e democráticos controlados e suprimidos de cima para baixo. Com o arranjo monárquico, enraizou-se o passado colonial (escravista e absolutista), dando seguimento, ao longo do século XIX, ao lusitanismo atrelado à Independência, o que só é quebrado pela pressão de interesses externos, especialmente dos ingleses (estes, manifestados também por pensadores do Brasil). Conforme Ianni (1994) descreve:

Os movimentos e as ideias comprometidos com a república e a democracia foram derrotados, controlados ou simplesmente suprimidos. Aos poucos, o manto monárquico recobriu muitas inquietações e desigualdades, criando a ilusão de que o poder moderador resolvia de forma benigna a maior parte dos problemas criados com o escravismo, as nações indígenas, a questão agrária, as diversidades regionais. Muitas inquietações se apagaram em diferentes lugares, dando oportunidade aos arranjos da conciliação pelo alto (Ianni, 1994, p. 13) [grifo nosso].

Na segunda metade do século XIX os 'surtos' de prosperidade da produção capitalista proporcionaram ao Brasil um avanço econômico que impactou em um grande aumento na exportação nacional, principalmente pelo progresso continuado da cafeicultura, caminhando pela Baixada Fluminense, o Vale do Paraíba e o Oeste Paulista e, ainda, pela cana de açúcar, o algodão, a borracha (Ianni, 1966). Concomitantemente a essa expansão da segunda metade do século XIX, com um ritmo de mortalidade superior ao de natalidade entre os escravizados, ocorre uma escassez no fornecimento de trabalhadores. Somando-se a isso a crescente tendência à condenação moral, pois nesse plano: "[...] a escravidão estava condenada por contradições insuportáveis para os agentes da situação [...] O princípio da igualdade dos homens perante Deus precisava ser instaurado 
também na esfera do comportamento efetivo das pessoas. Os subterfúgios utilizados pelos senhores de escravos, até meados do século XIX, já se haviam tornado gastos e insustentáveis" (Ianni, 1966, p. 15).

Com a contradição entre a mercadoria e o trabalhador escravizado, depois de vários séculos, se tornando insustentável para o mercado capitalista durante o século xIX surge a necessidade de superá-la. Sendo o escravizado um mero meio de produção colocado lado a lado da terra, da matéria prima, da tecnologia e passível de negociações por sua posse e, ao mesmo tempo, tendo uma vida produtiva (sujeita à doença e à morte) pouco a pouco ele passa a representar nesse sistema um capital suscetível à perda total e, nesta conjuntura, mostra-se ser uma escolha 'irracional' investir no trabalhador escravo ao invés do trabalhador livre (Ianni, 1966).

A transformação da figura do fazendeiro em empresário amplia, mesmo para os cidadãos de ciclos menos privilegiados, a compreensão da contradição entre mercadoria e escravo como também a contradição entre escravidão e liberdade. Como observa Ianni (1966, p. 43) esses cidadãos "reconhecem que a liberdade e o progresso estão na dependência da modificação das instituições que sustentam os privilégios presentes. Por isso, evidencia-se o caráter retrógrado da escravidão" -ou, em outras palavras, entendendo que a emancipação do valor de troca requer a eficiência do valor de uso.

A explicação racional que se dá à libertação dos escravizados é a de que, para que a atividade produtiva seja plena, é necessário que o trabalhador deixe de ser considerado mercadoria mercantil e seja livre, pois na condição de cidadão: "ele venderá a sua força de trabalho no mercado, segundo as tendências da oferta e da demanda. [...] Depois de ter atingido a unidade produtiva e o empresário, a racionalidade inerente à economia mercantil alcança também a esfera das expectativas e do comportamento do trabalhador. Assim o escravo se torna operário" (Ianni, 1966, p. 44).

Com a libertação dos trabalhadores escravizados, contextualiza-se a prática do lucro como função da mais valia relativa e da divisão do trabalho como forma de racionalização da produção, visando o progresso desse sistema. Em outras palavras, a transformação do escravo em 'cidadão' é só uma consequência desse novo regime.

Quando o negro escravizado foi liberto e colocado formalmente na condição de trabalhador livre, essa formalidade -em face à imigração e a grande naturalização- não se converteu em prática. O negro não foi aceito ao lado de trabalhadores brancos, porque não lhe foram desprovidos dos meios socioculturais e, principalmente, porque ele foi liberto na condição alienada, cabendo-lhe apenas compreender que a única forma de subsistir seria através da venda de sua força de trabalho - esta, por sua vez, inviabilizada pela barreira da especialização que lhe faltava. Em outras palavras, psiquicamente e socioculturalmente o cidadão negro ainda era um escravizado (Ianni, 1966).

Apesar da campanha abolicionista gerar modificações econômicas que impactaram na sociedade, essas transformações não foram profundas e radicais o suficiente para afetar o sistema social e nem o pensamento dos homens que o cerca uma vez que o "branco continuou ainda a identificarse ao senhor, ao grupo dominante; e o negro continuou, por sua vez, associado ao servidor" (Ianni, 1966, p. 50).

Em reação a estes acontecimentos, a história do pensamento brasileiro ganha as mais diversas e diferentes perspectivas, com teorias que caem na opinião coletiva em ambientes universitários, sendo constantemente continuadas e inovadas. Ou seja, as ciências sociais nascem aqui sob o desafio de compreender e viabilizar o Brasil moderno (buscando por raízes próximas ou distantes a compreensão do presente). Por outro lado, há também um ilusório fascínio pela modernidade, que faz com que -sem nenhum questionamento - pensadores brasileiros se adequem, de forma 
assimétrica às modas norte americana e europeia, tornando a ideia do Brasil moderno uma caricatura: alheia à historiografia; grotesca na aceitação passiva de conceitos e temas superpostos sem recortes (Ianni, 1994).

Posteriormente, na passagem do século XIx para o século xx, emergiu-se a preocupação de se pensar sobre o Brasil moderno que inevitavelmente viria, com todos os paradigmas sociais que acompanhariam o fim do trabalho escravo e do regime monárquico, preocupação essa que se expressava tanto em quem se posicionava contra quanto quem se posicionava a favor destas mudanças. A multiplicidade de interpretações e formulações é vasta e as propostas vão desde uma revolução a uma modernização conservadora (Ianni, 1994).

O processo de revalorização do trabalho do negro, em prol de interesses de concentração de capital da burguesia dependente, ocorre lentamente, em concomitância com o processo de ressocialização do negro e que só se torna viável por conta das transformações do sistema social. Por meio das modificações nos padrões de socialização, o negro ajustava-se à sociedade de classes. Este processo de revalorização, na ideologia racial do branco, abre espaço para o mito da democracia racial (sob a justificativa de "irmandade perante Deus"). No processo de redefinição do negro:

[...] não faltarão elementos das condições histórico-econômicas e sociais do passado. Atributos e avaliações relativos aos escravos sobrevivem, reformulados, revelando uma tenacidade da ideologia racial do branco que o ritmo lento das transformações econômicas básicas explicam. Os próprios elementos destinados à redefinição ideológica do negro denunciam essa persistência. Ao lado da reavaliação do trabalho, perduram avaliações negativas polarizadas em torno da cor. Como se lê num editorial de 1930, em A Tarde a escravidão é 'negregada instituição', alguns brancos são cognominados 'brancos de alma preta' e certos políticos fautores de 'negrada política' (Ianni, 1966, p. 75).

Neste período, a tentativa de compreensão do Brasil apesar de ser movida pelo interesse em estimular a modernização nacional, se divide em dois interesses principais:

Primeiro, no sentido de fazer com que a sociedade brasileira e o Estado [...] se aproximem dos padrões estabelecidos pelos países capitalistas mais desenvolvidos. Segundo, no sentido de conhecer, valorizar ou exorcizar as peculiaridades da formação social brasileira, tais como os séculos de escravismo, a diversidade racial, a mestiçagem, o trópico, o lusitanismo, o europeísmo, etc. É óbvio que esse esforço de compreensão e compromisso não se organiza sempre na mesma direção. Uns preconizam a modernização em moldes democráticos; outros em termos conservadores, ou simplesmente autoritários (Ianni, 1994, p. 47).

Neste cenário, a nação republicana entra em processo de transformação questionando os séculos de escravismo, as formas de "legitimidade" da monarquia junto às heranças sociais e culturais advindas da cultura de castas. Toda essa transformação social tem como base o ciclo de café, tanto por seu valor econômico, com a exportação; quanto por seu valor político e social com a ascensão do fazendeiro à figura de "elite social". Desta forma a economia cafeeira se sedimentava aos moldes capitalistas e a partir daí desenvolvia-se o mercado interno, formando assim as classes sociais na cidade e no campo. Acompanhando esse ritmo, a Abolição e a República se mostravam vantajosas dentro dos moldes de racionalidade do "homem de negócios" (Ianni, 1994). 
Assim, a presença do negro na história do Brasil é problematizada de forma muito mais obsessiva do que a de indivíduos de outras etnias, no pensamento e na prática de quem procura compreender a formação do povo, cidadão, sociedade civil e Estado nacional (Ianni, 1994). A problemática de como se dá a transformação da população de trabalhadores em um povo aparece muitas vezes implícita e esteve presente na Colônia, no Império e nas Repúblicas, nos escritos de diversos autores continuamente comprometidos com o modo pelo qual o negro se insere na fisionomia do povo, na formação da sociedade civil, na história da nação.

Após passar por essa linha do tempo acerca da problemática racial, colocando em perspectiva ampla, é possível notar que seu debate é feito em uma forma de exorcismo, que procura explicar as lutas sociais em termos raciais, em busca das raízes do atraso e do fanatismo das multidões (por meio de determinismos geográficos e raciais, travestidos de "antropologia científica"), ao tempo em que se esquecem de compreender as condições políticas e econômicas que levam às desigualdades sociais (Ianni, 1994).

É importante ressaltar que, além dos interesses pela concentração do capital por trás desta política, a ausência de uma identidade é um fator determinante no caráter do desenvolvimento, pois ele é dado pela forma que a sociedade dependente lida com as "contradições geradas pela discrepância entre a aspiração de acesso ao estilo de vida do capitalismo central e a situação de atraso da sociedade dependente" (Sampaio Júnior, 1999, p. 143). A forma que a burguesia encontra para se colocar no fluxo material e cultural do capitalismo central é por meio da cópia de modelos mais avançados de economia através da modernização induzida (Fernandes, 1972).

A respeito da burguesia nacional é necessário destacar que, apesar de expressar interesses sociais no mercado nacional, ela é dependente de interesses estrangeiros do imperialismo. Mediante essa dependência, somente por meio de alguma divergência neste ponto é que surge alguma oposição - mas sempre com tendência à apaziguamento desse sistema (não sendo assim uma oposição radical, bem estruturada ou necessariamente política). Sobre esta burguesia nacional Ianni (1994) afirma que:

ela existe e não existe. Existe como expressão de interesses de setores sociais ligados à indústria, agricultura, comércio e banco. Há empresas pequenas, médias e grandes baseadas no mercado nacional e compostas de capitais nativos, além de explorarem a força de trabalho local. Podem lutar e lutam contra empresas estrangeiras que invadem as suas áreas de atuação, as suas bases de organização. Podem revelar as suas reivindicações e os seus interesses em associações, sindicatos, partidos e meios de comunicação, bem como nos lobbies mais ou menos visíveis que atuam nas esferas do poder governamental [...]. Esta burguesia, no entendo, não se manteve nem se mantém independente. Devido a injunções econômicas, tecnológicas, políticas e outras, são levadas a acomodar-se e associar-se (Ianni, 1994, p. 67-68).

No topo desta estratificação os efeitos dessa heterogeneidade anacrônica do sistema produtivo também atingem psicossocialmente a burguesia dependente (ao ponto de se trocar uma possível equidade social por, no máximo, caridade) (Sampaio Júnior, 1999).

A burguesia dependente, alheia a um projeto de desenvolvimento social nacional, ao invés de ampliar sua visão de classes e propor alianças para um crescimento conjunto, teme a força política dessas classes. A contradição dessa burguesia está no fato de que, quando necessita se defender do "imperialismo", recorre às "massas"; e quando se vê desafiada pelas massas, se vale da força 
das nações imperialistas. Se temos a marca de poucos avanços em um contraste assimétrico de contínuos recuos na democracia brasileira, isso se deve ao caráter restritivo, autoritário e antidemocrático desta burguesia. Ianni (1994, p. 69) argumenta que ela não tem compromisso com a democracia uma vez que "não construiu nem constrói um projeto de cunho hegemônico, porque não interpreta os interesses das outras classes e muito menos da sociedade como um todo".

Além do controle da classe dominante, há também outra contradição que distancia a classe proletária da classe dominante, aqui, como nosso foco: o problema racial.

o fato de que a revolução burguesa não resolveu o problema racial acaba por criar outra gama de contradições sociais. Junto com as contradições de classes, desenvolvem-se as contradições raciais. Em muitos casos, o camponês é também negro, mulato, índio ou caboclo. Da mesma forma, o operário e outras categorias de trabalhadores. As várias classes sociais reúnem inclusive as reivindicações de cunho racial, cultural e regional (Ianni, 1994, p. 138).

Além da ausência cultural de uma identidade nacional, a classe operária (majoritariamente negra) é estruturalmente impossibilitada de se ver como tal e, a partir daí, desenvolver sua autonomia, pois "as distorções no processo de mercantilização do trabalho levam à segmentação da classe operária em setores extremamente heterogêneos" e, junto a isso, "as oportunidades de mobilidade social abertas pelo crescimento econômico facilitam a cooptação da 'elite' operária” (Sampaio Júnior, 1999, p. 146), fazendo com que esta classe não se identifique ao ponto de negar com lucidez o capitalismo dependente.

O caráter de destruição identitária da sociedade dependente é parte da prática de dependência que a burguesia perpetua e é precisamente sintetizada por Fernandes ao afirmar que:

ela deprime, solapa ou neutraliza, por vários modos e vias, a classificação, a diferenciação, a participação e a integração das camadas assalariadas, pobres ou despossuídas, ela carece de poder de mobilização efetivo, capaz de servir como fulcro de redefinição das relações de classe e de recomposição das posições relativas das classes entre si. A ordem social competitiva funda-se de tal maneira em desigualdades extremas e nas barreiras que permitem mantê-las, ao mesmo tempo, em crescimento paralelo com a expansão gradual do regime de classes, que ela se anula como ponto de partida de transformações radicais do status quo. Ela não confere ao despossuído, ao pobre, ao operário potencialidades para contrabalançar as influências exorbitantes das classes 'altas' e 'médias' ou para desencadear movimentos sociais suscetíveis de conduzir ao controle da dependência e do subdesenvolvimento dentro do capitalismo. Ao condenar ao ostracismo e à participação segmentária ou marginal suas classes 'baixas', as sociedades nacionais da América Latina não só destroem as identificações larvárias dessas classes com a ordem social competitiva e dissipam suas 'compulsões burguesas'. Elas também se condenam à eternização da dependência e do subdesenvolvimento, mediante a institucionalização do capitalismo selvagem (Fernandes, 1976, p. 84).

A ausência de uma identidade é o que mantém às classes exploradas a impossibilidade de formação de condições objetivas e subjetivas "para que a luta de classes seja guiada por uma lógica baseada na busca do bem comum” (Sampaio Júnior, 1999, p. 147). Conjuntamente, a sacralização 
da propriedade, vinda da burguesia, faz com quem, por temer a perda de seus privilégios mediante as revoluções tecnológicas dos países de centro, se aliene à "possibilidade quase ilimitada de manipular as condições socioeconômicas internas a fim de perpetuar a superexploração de trabalho e a dilapidação dos recursos naturais do país" (Sampaio Júnior, 1999, p. 147).

Portanto, sendo a universalização da ordem social competitiva em território nacional uma expressão da estruturação estatal advinda da revolução burguesa, com o propósito de criar condições de identificação positiva das classes sociais para com o regime burguês, a negligência acerca da identidade do proletariado (majoritariamente negro) é de grande interesse para a burguesia.

A revolução burguesa em nada resolveu o problema racial -muito pelo contrário: as diferenças raciais estão impressas nas categorias do proletariado e nas classes sociais de forma generalizada. Ao contrário, a revolução burguesa se ateve a ajustar o trabalhador às exigências do mercado, transformando escravizados em "iguais e livres" na condição de proprietários de sua força de trabalho, gerando uma coletividade de trabalhadores.

O camponês, operário rural, operário urbano, empregado, funcionário e outras categorias de trabalhadores continuam a defrontar-se com as diferenças raciais, além das de classes. Mais frequentemente, as desigualdades sociais compreendem e mesclam diversidades raciais e de classes sociais. Sem esquecer as diversidades de cunho regional, religiosas, culturais e outras, presentes nas condições de trabalho e vida de todos (Ianni, 1994, p. 137).

Apesar da instituição jurídica de que “todos são iguais perante a lei”, essa formalidade não chega ao campo da prática ao se deparar com a prática da continuidade da tese de povos históricos e povos não históricos. O que há na prática é uma gritante diferença social, que mantém a desigualdade racial e as diferenças entre classes -que não proporciona à imensa maioria dos proletariados a condição real de cidadãos.

Apesar de movimentos sociais mostrarem alguma resistência, eles são constantemente inviabilizados violentamente pelas classes dominantes (essas, vale lembrar, com a intervenção do Estado a seu favor). As classes dominantes, por fim, capitalizam e jogam com as demais classes sociais para manterem seu poder, justamente por verem nelas uma ameaça aos seus privilégios (Ianni, 1994).

O Brasil, em um sentido social, não pode ser reconhecido como uma nação (no máximo como um forte Estado Nacional). Sua totalidade não pode ser expressa por suas partes, graças à sua profunda desigualdade entre unidades administrativas e seus segmentos sociais. Sua desarticulação é tamanha que as divisões entre estados e regiões, por um lado, e grupos e classes, por outro, torna sua totalidade algo alheio às suas partes.

É tão marcante a imposição das forças de dispersão que a consequência disso, dentro deste quadro, se manifesta na impossibilidade de desenvolver um todo superior, no qual todas as suas partes se beneficiam e concomitantemente se tornam superiores. Mesmo quando são adotadas políticas equitativas (COMO O DNOCS, a SUDENE, a SPVEA ou a SUDAM) ${ }^{2}$ as desigualdades terminam por se acentuar quando essas políticas são instrumentalizadas por forças mais poderosas e seus objetivos terminam por ser distorcidos. Apesar de existirem institutos jurídicos-políticos com o objetivo de

${ }^{2}$ Departamento Nacional de Obras Contra a Seca (DNOcs), Superintendência para o Desenvolvimento do Nordeste (sudene), Superintendência do Plano de Valorização Econômica da Amazônia (spvea) e Superintendência do Desenvolvimento da Amazônia (SUDAM). 
promoção de equidade entre grupos raciais (no sentido sociológico) e classes sociais, existem forças sociais mais poderosas que se valem do fato de que a população ainda não se tornou um povo e que mantêm e expandem em benefício próprio esta desarticulação (Ianni, 1994).

Apesar desses fatos, a questão nacional continua aberta pela razão de que, até fins do século xx, a sociedade brasileira ainda não solucionou eficientemente a questão racial e ainda hoje continua buscando por sua fisionomia.

\section{Segundo limite: a questão racial no desenvolvimento desigual}

De acordo com Florestan Fernandes, para que a burguesia contrabalanceie a instabilidade do capitalismo dependente e promova um mínimo de estabilidade em benefício próprio, é necessário que haja o mínimo de autonomização do capitalismo local e isso só é possível através de um sistema produtivo heterogêneo, colocando em coexistência diversas fases da produção, pois "a partir de o momento em que a articulação internacional provoca um deslocamento de fronteiras econômicas e culturais ela põe a organização da economia periférica e seu padrão de desenvolvimento na órbita de uma revolução econômica" (Fernandes, 1976, pp. 237-238).

Em que pese o pensamento de que as formas arcaicas dentro do capitalismo dependente são uma espécie de resquício de uma suposta "evolução linear" do capitalismo, na realidade, sua existência tem uma função proposital, conforme descreve Fernandes (1972) ao afirmar que "a exploração dessas formas, e sua combinação com outras, mais ou menos modernas e até ultramodernas, fazem parte do 'cálculo capitalista' do agente econômico privilegiado”. Com base nesta tese, Sampaio Júnior explica que, de forma implícita, a premissa é a de que: "a articulação de estruturas modernas e atrasadas é um expediente que permite às burguesias dependentes compensar a debilidade de sua estrutura de capital e o circuito de indeterminação gerado pela extrema precariedade da conjuntura mercantil em que vivem" (Sampaio Júnior, 1999, p. 137).

Ou seja, a precariedade dessa estrutura nada mais é do que uma ferramenta de transferência de renda para os países imperialistas e de manutenção de poder da burguesia local, mediante a instabilidade provocada pelas revoluções tecnológicas dos centros. Sampaio Júnior (1999) explica que essa transferência de renda e como ela amortece os impactos dessas revoluções com base na exploração dos mais pobres.

O proposital e funcional dualismo existente no Brasil é grande ao ponto de ser possível viajar no tempo apenas se deslocando de espaço. Esse feito, do qual a burguesia se serve do melhor dos dois mundos, possibilita que se mantenha seu status econômico e social, pois: "a articulação de formas de produção heterogêneas e anacrônicas entre si preenche a função de calibrar o emprego dos fatores econômicos segundo uma linha de rendimento máximo, explorando em limites extremos o único fator econômico constantemente abundante, que é o trabalho" (Fernandes, 1972, pp. 64-65).

Esse mínimo de estabilidade promovido pelo desenvolvimento dependente à burguesia despeja sobre as classes menos favorecidas o ônus da perene impossibilidade de ascensão, pois ela não "compromete o papel da concorrência como modo autônomo de articular a ordem econômica" (Sampaio Júnior, 1999, p. 139).

Apesar dessa dualidade permitir a possibilidade do desenvolvimento autônomo, ela, ao mesmo tempo, serve como uma trava e inviabiliza as chances dessa autonomização ganhar força o suficiente para se expandir e se democratizar (ou seja, apesar da inibição das forças produtivas até 
o ponto em que é dificultada e inviabilizada a expansão capitalista fora dos limites dessa dependência, as forças de organização capitalista -nas mãos da burguesia- não são prejudicadas) (Fernandes, 1972).

Dando força à ausência de uma identidade, o regime de classes opera como instrumento de acúmulo de poder da burguesia dominante, permitindo uma concentração deste em posições estratégicas, a fim de impossibilitar profundas mudanças socioculturais.

Com base neste fator a exclusão social é perpetuada, pois a sociedade passa a ser dividida entre possuidores e não possuidores de bens e, visto que "a assimetria no regime de classes tem profunda influência sobre a formação de atores sociais” (Sampaio Júnior, 1999, p. 144), a população não branca do Brasil -que nunca vivenciou de fato uma democracia racial- tende a ser profundamente prejudicada com o racismo que se recria no Brasil.

Apesar das diferenças entre as classes dominantes, a repulsa das burguesias dependentes por iniciativas de transformação social é tão grande que, tendo as classes subalternas como um só inimigo em comum, elas se unem em prol da manutenção de seus privilégios advindos da concentração de poder. Diante dessa situação "a unificação da burguesia como classe dominante torna-se uma questão eminentemente política que se define por intermédio do Estado” (Sampaio Júnior, 1999, p. 148). Conforme Fernandes argumenta que "os privilégios -e não os elementos dinâmicos do 'espírito capitalista'- cimentaram essa espécie de solidariedade de rapina (...)” (Fernandes, 1976, p. 108).

O viés imediatista das classes dominantes é subsequente da visão apequenada destas ao não pensar no desenvolvimento para além do próprio enriquecimento e, por conta disso, "a união destes interesses, assim estabelecida, transforma-se na verdadeira espinha dorsal do subdesenvolvimento, porque nenhuma categoria econômica da burguesia considera legítimo ou dispõe de meios eficientes para romper, em termos puramente econômicos, com o pacto sagrado" (Fernandes, 1976, p. 108).

Os valores democráticos da civilização burguesa, apesar de admitirem a acumulação de capital, rejeitam a democratização dela na comunidade nacional e concentram os privilégios para si mesma. A legitimação desse processo é feita por meio do Estado.

Apesar da hegemonia da classe dominante, ela comporta a dicotomia entre os setores "conservador" e "modernizador" (ambos subservientes do imperialismo e incapazes de enfrentar seus obstáculos internos e externos). Apesar da divisão, a divergência entre esses dois grupos se expressa de uma única forma: pelo "grau de marginalização em relação ao processo de modernização difundido do centro capitalista que consideram tolerável” (Sampaio Júnior, 1999, p. 152).

A miopia das classes dominantes na sociedade dependente é tamanha que, em meio à preocupação excessiva com a estabilidade política do país, ela mesma restringe sua possibilidade de mobilização do Estado para que se defenda seus próprios interesses a médio e longo prazo. Conforme argumenta Fernandes, "qualquer inovação, em particular, e o processo de modernização, em geral, são avaliados e repelidos ou aceitos num contexto de extrema irracionalidade" (Fernandes, 1972, p. 121).

A expansão dos setores não agrícolas (artesanais e fabris), por sua vez, incentiva um mercado de mão de obra baseado no trabalhador livre e, junto a isso, a distinção e valorização do trabalhador imigrante em detrimento do escravizado ou ex-escravizado.

A saber que a transformação do trabalho escravo em trabalho livre não transformou totalmente a estrutura econômico-social, é possível afirmar que as assimetrias do regime escravista mantiveram-se dispostas em camadas sociais na sociedade que a sucedeu. Nesta sociedade de 
classes, apesar do trabalhador livre, em face ao ex-escravizado, estar em posição de vantagem, este proveito se torna relativo diante do fato de que o verdadeiro domínio da sociedade continua nas mãos dos proprietários dos meios de produção.

Neste novo contexto, nas décadas iniciais do século xx, a ideologia racial do branco se desdobra em duas ressignificações: a da revalorização do trabalho humano e a do mito da democracia racial no Brasil. Ianni (1966) mostra que o engajamento da comunidade em relação a necessidade de substituição do trabalho escravo frente o trabalho livre (dentro da dicotomia de trabalho amaldiçoado versus trabalho digno moralmente), avança gradualmente com as mudanças nas condições de produção.

A questão social, com seus múltiplos aspectos e diversas formas de manifestação, pode desencadear tanto em reformas quanto em revoluções. A partir de aí surgem políticas de setores públicos e privados, cultuando convicções ao ponto de qualificar manifestações como um problema de polícia ou militar. Por sinal, vem do passado a inclinação dos setores sociais dominantes em reagir com extrema intolerância em face de reivindicações e a olhar para o povo com um olhar meritocrático, culpando-o por sua própria miséria.

Portanto, é possível compreender que esse modelo de economia dicotômica envolve os "participantes" e os "excluídos" economicamente, e tem seus progressos baseados na pauperização relativa ou absoluta. Diante dessa problemática, mostra-se conveniente a uma parte do pensamento social naturalizar este fato e taxá-lo apenas como uma "fatalidade".

O desemprego e o subemprego são manifestações dos fluxos e refluxos dos ciclos dos negócios. A miséria, a pobreza e a ignorância, em geral, são ingredientes desses processos. O contingente de trabalhadores de reserva tem sido um elemento altamente conveniente para a empresa e a fazenda, no sentido de reduzir os custos da mão-deobra para o comprador, além de facilitar a divisão da classe operária, enfraquecendo-a em seus sindicatos, partidos, movimentos sociais. É enganoso sugerir que os 'dois' brasis pouco ou nada têm a ver um com o outro (Ianni, 1994, p. 99).

A partir disso, as soluções mais recorrentes (dadas juntas ou separadas) são: a transformação desta "fatalidade" em problemática de assistência social ou no velho problema de polícia -via violência e repressão. Essas medidas visam sempre a manutenção do statu quo a fim de manter grupos e classes sob controle em nome de uma (enviesada e restrita) "paz social”. Essa criminalização do "outro" é uma forma de negligenciar urgências sociais.

Neste clima são veiculadas campanhas para exorcizar padrões e valores atribuídos no período do escravismo -como, por exemplo, a do personagem Jeca Tatu, de Monteiro Lobato, criticando o modo de vida caipira presente no Vale do Paraíba. O discurso de beatificação do trabalho surge em função de "que ele ganhe dignidade, a sociedade progrida e o capital se multiplique. Daí o combate sem trégua à preguiça” (Ianni, 1994, p. 106).

Portanto, nota-se que o desenvolvimento dependente não promove um ambiente competitivo e progressivo em linearidade, dentro de um Estado plenamente democrático. Pelo contrário, os resquícios coloniais perpetuam. Contudo que o crescimento econômico -elemento utilizado pela burguesia dependente como um dos padrões de dominação- alimente o mito de melhor classificação social, ele não é necessariamente uma resolução ou contrapeso para os problemas provenientes da dependência. 
Com a burguesia promovendo o capitalismo dependente por via autoritária da subutilização do proletariado, a exclusão das classes subalternas em relação ao meio político tem o propósito de eliminar a única via pela qual a burguesia poderia ter seu ciclo vicioso rompido (Fernandes, 1981).

É necessário ressaltar que a revolução burguesa tem características próprias em relação a cada modelo de sociedade. No capitalismo dependente, entre suas particularidades internas e externas, ela tem como centro a restrição sobre a possibilidade de conciliação entre transformações capitalistas e integração social, em que, diante da subserviência ao imperialismo, a manutenção do estado de dependência e do subdesenvolvimento é estratégica - conforme afirma Sampaio Júnior, a intransigência na defesa do status quo "restringe o espaço para composições e compromissos com as classes subalternas, o que bloqueia a emergência das classes populares na arena política" (Sampaio Júnior, 1999, pp. 158-159). Descrevendo a revolução burguesa como um processo político, Fernandes argumenta que a economia dependente só compreende "as transformações capitalistas que são compatíveis com a perpetuação do ultraprivilegiamento econômico, sociocultural e político das classes dominantes" (Fernandes, 1976, p. 318).

Com a acentuação da divisão do trabalho, a partir de fins do século XIX, a estrutura demográfica se ressignifica ao ponto de delinear as atividades exercidas, promovendo assim atributos na estrutura econômico-social -ou seja, a distribuição das hierarquias dentro desta estrutura aprofunda a assimetria das relações e intensifica as discriminações (Ianni, 1966). Ianni ao tentar exemplificar essas assimetrias, toma o exemplo de Curitiba -a capital considerada "mais branca" do Brasil. Com as transformações sociais intensificando a divisão do trabalho, entre as décadas de 1940 e 1950, em Curitiba, diversifica-se a estrutura ocupacional da cidade. Ou seja, somente depois de um longo período que houve a possibilidade de negros e mestiços se ajustarem economicamente à camada inferior da sociedade- com raras exceções de seus membros ingressando na classe média.

Nos dados do IBGE, relativos ao grau de instrução da população, segundo a distribuição de cor, em 1950 (em pleno processo de democratização), o fenômeno se mostra similar ao se medir o índice de analfabetismo, sendo $74.03 \%$ dos negros, $71.26 \%$ dos mestiços, $32.24 \%$ dos amarelos e $51.74 \%$ dos brancos. É importante observar que, com a acentuação da divisão do trabalho em Curitiba, o grau de instrução consiste em um requisito para a ascensão social (inclusive para a própria condição proletária). Ianni (1966) argumenta que essa relação do proletário ser alfabetizado ou não deixa de ser uma alternativa, mas sim um 'requisito essencial' como consequência do aprofundamento da divisão do trabalho e maior complexidade do mercado de trabalho.

Apesar de ser possível atribuir a disparidade entre esses grupos como uma relação econômica, é indispensável uma análise social desta relação. Neste sentido, o primeiro fenômeno observável acerca da demografia de Curitiba é a pequena presença de negros e mestiços e a grande desigualdade étnica e racial (Ianni, 1966). O impacto dessa formação econômico-social e humana de Curitiba é refletido na sólida estrutura de classes sociais hierarquizadas, com uma população de negros e mestiços numericamente menor e com a população total condensada demograficamente em setores específicos. Nestas condições a relação entre negros, mestiços e brancos é guiada pelas condições de classe, sob o véu das heranças ideológicas do passado.

O desenvolvimento desigual e combinado incumbe a classe operária a cumprir tarefas que a revolução burguesa ignorou mediante os confortos de sua privilegiada "subalternidade com regalias" frente ao imperialismo. O contato, principalmente do trabalhador do campo com a cidade, por meio do choque e mescla de contradições, tem potencial para favorecer a criação de uma classe operária nacional, capaz de intervir nos compromissos das classes dominantes "nacionais" com as estrangeiras. 
Por essa razão a revolução precisa configurar-se em uma ruptura e modificação das relações internas, se atendo a diminuir e eliminar desigualdades explicitas e veladas presentes nas estruturas e relações sociais, visando essencialmente suprir as necessidades de seu povo. Esse processo de revolução teórico-prático requer a interpretação dialética da "desagregação" social brasileira, para que a revolução entre em andamento.

Com a Abolição houve a abertura para o debate, mesmo diante de toda a violência do poder estatal e privado. Vagarosamente, sem abrir mão dessa violência, alguns setores dominantes e governos passam a reconhecer a questão social como realidade e a partir de então considera-se alguma negociação, tendo como centro o não abalo do statu quo a partir desta consideração que, vagarosamente, a questão social começou a ser tratada como um problema político ao invés de um problema de política. Em contraponto a esse ínfimo progresso, muitos são os retrocessos, voltando-se novamente ao trato desses problemas políticos como problema de polícia (Ianni, 1994).

Nesse ritmo, chega-se à Nova República de 1985, com um grande crescimento econômico, mas com uma desigualdade gigantesca na distribuição, com problemas como a fome, desnutrição, falta de habitação e precariedade nas condições de saúde. Essas desigualdades são estruturadas em processos como o desenvolvimento exacerbado do capitalismo (que provoca o deslocamento dos trabalhadores), os surtos, fluxos e refluxos de industrialização e urbanização, os surtos de atividades agrícolas, dentre outros (Ianni, 1994).

Ao se colocar o trabalho no centro dessa questão, visando às condições de oferta e de demanda de força de trabalho, alguns pensadores começam a reconhecer que o "protecionismo" e o "intervencionismo" do Estado brasileiro, quando existentes, favorecem apenas às classes patronais. Posta em mesa essa necessidade, iniciou-se um processo de redefinição ideológica (baseada no mérito) para quebrar o estigma - produzido ao longo da Colônia e Império, que valorizou o senhor, branco, rico, administrador e proprietário - de que o trabalhador braçal era inferior. Cabe às Repúblicas o papel de valorizar o trabalho como atividade dignificante. Vale dizer que uma das formas de "dignificação" do trabalho é a valorização da imigração e da colonização para substituir o escravizado.

Ao longo de toda a história brasileira, o paradigma racial foi e continua a ser um ponto chave para a compreensão das particularidades da sociedade. Seja a curiosidade acerca da mescla de "raças" e seu impacto sobre a característica de híbridos em seu papel social, ou mesmo um complexo de grupos raciais e classes sociais. A partir desse ponto, abre-se o debate acerca da compreensão da metamorfose do povo, envolvendo características genéticas, fenotípicas e outras das "três raças", das quais são delegados atributos morais, psicológicos e culturais, de acordo com cada "raça". Por meios dessas delegações criam-se as construções sociais de puros e impuros, superiores e inferiores, civilizados e bárbaros (Ianni, 1994).

Considerando-se a expressão cultural como algo vivo, que se reinventa em meio às relações sociais, é necessário compreender que ela também pode ser compreendida como uma visão subjetiva a uma posição social. Muitas das desigualdades terminam por veladas ou simplesmente naturalizadas, sob o manto da subjetividade do significado de palavras, metáforas, signos e idolatrias. Até mesmo a diferença de dialetos entre falantes do mesmo idioma ajuda a intensificar as desigualdades vigentes (Ianni, 1994).

Histórica e socialmente falando, o debate sobre a cultura dá abertura ao debate da questão nacional, recolocando o tema da dicotomia entre as culturas dominante e subalterna em contraste com a nação. Essas produções culturais natural e inevitavelmente são sujeitas a vieses de grupos e classes, o que significa uma pluralidade de narrações acerca de um mesmo objeto e, a partir 
de aí, abre-se mais um vão para se revelar novas perspectivas da história e questionamentos: "aos interesses de quem?”; “a quem representa?”. Ianni argumenta: "É claro que a história narrada pelas classes dominantes não é a mesma, sempre. É reinterpretada em cada época, conforme a força do bloco de poder que emerge do jogo político, lutas sociais. Também os camponeses e operários, ou índios, negros e brancos, contam e recontem a sua estória, o seu causo" (Ianni, 1994, p. 149).

Apesar dos avanços da revolução burguesa (no que diz respeito à economia, desenvolvimento de capital e acumulação), Ianni afirma que:

[...] pouco avançou a revolução burguesa em termos políticos e culturais, se pensamos a partir da perspectiva de operários, camponeses e outros setores populares. As conquistas democráticas, em forma política e cultural, são limitadas. Com frequência há retrocessos. Sucedem-se os golpes de Estado, arranjos de cúpula, conciliações pelo alto. Classes dominantes, associadas com as altas hierarquias militares e da Igreja, sempre com a colaboração de setores do imperialismo, criam e recriam blocos autoritários. Assim se interrompem processos democráticos, nos quais operários, camponeses, empregados, funcionários e outras categorias sociais lutam para conquistar direitos, abrir espaços políticos e culturais (Ianni, 1994, p. 151).

\section{Terceiro limite: a questão racial na dependência}

As bases nacionais das diversidades e desigualdades são estabelecidas, em grande parte, pela economia primária exportadora, posta em prática entre os séculos XVI e Xx. A começar pelo fato de que não só a história foi formada por uma sucessão de ciclos, da qual:

[...] atividades econômicas predominantes, aqui ou lá, voltadas para o mercado externo, marca os lineamentos dos estados e regiões da geografia e história. Assinalam os movimentos do povoamento, colonização, escambo, escravidão, fazendas, engenhos, sertões, fronteiras, povoados, cidades, províncias, estados e regiões. É aí que se enraíza o desenvolvimento desigual e contraditório, característico da economia e sociedade no Brasil (Ianni, 1994, p. 167).

Portanto, apesar das diversidades de produção presentes em cada canto do país, a industrialização se sobrepõe a todas elas acentuando as desigualdades já existentes em cada uma dessas regiões.

Entre o século XIX e Xx, o eixo da sociedade brasileira deslocou-se para o centro-sul, ocasionando em uma intensificação de interesses econômicos, políticos e culturais que exerceu influência sobre todo o país. Com essa intensificação o pensamento social se expandiu na região, ao ponto de se tornar emergente a Abolição da Escravatura e a Proclamação da República para o desenvolvimento de uma economia propriamente nacional. Se nos períodos de Colônia e Império, com o eixo fixado no nordeste, ambos os modelos de economia eram vistos como "tropicais", com a produção de cana e café; no período da República, com eixo fixado no centro-sul, o modelo de economia industrial era visto como o responsável pelo povoamento (junto à recriação das desigualdade) nas cidades e pela invasão do campo. Em outras palavras, a mudança do nordeste para o centro-sul foi responsável pela implementação e expansão do capitalismo. "A vida econômica, política e cultural do país passou a ser progressivamente influenciada pelos interesses, os temas e as forças sociais que passaram a predominar no centro-sul, na esfera do poder estatal brasileiro, e, a partir daí, nas outras regiões do país” (Ianni, 1994, p. 174). 
As mudanças sociais necessárias ao Brasil são impossibilitadas pela ausência de alguns agentes necessários para impulsiona-las. Sampaio Júnior descreve que:

Por um lado, a possibilidade de desvincular a aceleração do desenvolvimento capitalista do processo de integração nacional leva as burguesias nacionais a optarem definitivamente por uma aliança estratégica com o capital internacional e com as nações hegemônicas. Por outro lado, o aprofundamento da industrialização exacerba o "medo pânico" das classes dominantes, levando-as a abandonar quaisquer veleidades revolucionárias e a assumir, sem hesitação, seu caráter autocrático (Sampaio Júnior, 1999, p. 162).

Dentre as ações ausentes necessárias para impulsionar mudanças sociais primordiais -como a equidade entre pessoas de fenótipos diferentes (que, para além dos preconceitos sociais, se traduz em uma luta de classes) - se destaca o não reconhecimento do capitalismo dependente, propositalmente negligenciado e utilizado pelos interesses da burguesia. A conscientização sobre os déficits sociais (de tal forma que inclui a conscientização acerca da disparidade existente de pessoas de fenótipos diferentes) e sua busca política por equidade não só representa uma mudança de paradigma do modelo de sociedade que vivemos como também uma verdadeira ameaça à fonte inesgotável de conforto da burguesia dependente (Sampaio Júnior, 1999).

Neste contexto, o estado de dependência aproveitado pela burguesia não só é um instrumento de manutenção de seus próprios privilégios como também uma contrarrevolução, em oposição à possibilidade da classe proletária rejeitar a situação de dependência e lhe tirar este privilégio.

Assim, para que a burguesia dependente se valha do capitalismo proveniente desta nova fase imperialista, é necessário que seja mantida permanentemente a cisão que mantém a dualidade entre a concepção e proveniente controle das premissas socioeconômicas e socioculturais fundamentais para o funcionamento de uma ordem social competitiva entre minorias privilegiadas e o processo de democratização de ordem social que compreende a população nacional. Uma forma de manter essa cisão velada e manter o modelo de capitalismo dependente é por meio da universalização de alguns interesses de classe, expondo-os e tratando-os como interesses nacionais. Em relação a este aspecto, Fernandes afirma que a:

[...] revolução nacional significa, em semelhante contexto histórico-social e político: (1) integração horizontal, em sentido e em escala nacionais, dos interesses das classes burguesas; (2) probabilidade de impor tais interesses a toda a comunidade nacional de modo coercitivo e "legítimo". Essa é a base política da continuidade da transformação capitalista e dela podem resultar, indiretamente e a largo prazo, consequências mais ou menos úteis para as demais classes e universais quanto aos dinamismos da comunidade nacional (Fernandes, 1976, p. 301).

Com o statu quo direcionado a manter o capitalismo dependente como a alternativa mais racional para as burguesias periféricas, os comportamentos e a consciência de classe surgem como uma consequência de tal e reforçam ainda mais as disparidades (com a burguesia dependente dissociada das mazelas de seu espaço-tempo -enquanto visa constantemente os padrões sócio-culturais dos países de centro- seus interesses se mantêm em preservar sua favorecida condição de dependência). A preservação interna desses anacronismos é uma ferramenta de manutenção desse 
poder, pois "as classes dominantes exacerbam as resistências sociopáticas à mudança e empenhamse ainda mais em evitar a abertura de espaço político para as classes subalternas” (Sampaio Júnior, 1999, pp. 164-165).

\section{A QUESTÃO RACIAL NA ÓTICA DAS INTERPRETAÇÕES DA LITERATURA MAIS RECENTE}

\section{Metodologia de Busca}

Para etapa de busca e análise dos artigos científicos mais recentes, trabalhamos com uma única base de dados Web of Science -SIBiUSP. A sintaxe de nossa busca foi definida a partir da tese da literatura abordada que considera a questão racial como uma barreira ao desenvolvimento econômico. Desta forma, foram utilizadas os termos: "racismo", "negro" e "desenvolvimento econômico". Para que a busca abrangesse tanto uma quanto outro termo, fizemos o uso de aspas e o uso do conectivo "and", como segue na sintaxe: "racismo" and "negro" and "desenvolvimento econômico". Nos filtros de identificação oferecidos pelo sistema, aplicamos em conjunto as opções "periódicos recentes”, "artigo" em "português" para estabelecer a especificidade das publicações de interesse e assim obtivemos 29 publicações. O período que foi considerado para a realização da busca das publicações foi junho de 2019. A rigor, não se restringiu um período para a captura das publicações, à medida que a temática é escassa na literatura brasileira.

Dessas 29 publicações, decidiu-se manter apenas os artigos científicos, excluindo as produções acadêmicas como monografias e teses, além de anais de congressos e publicações oficiais. Em seguida foi realizada leitura sistematizada dos títulos e resumos dos artigos restantes, mantendo apenas os artigos publicados em português e que dialogavam diretamente com a temática desta revisão. Dessa forma, foram excluídos 14 artigos, restando 15 artigos (51.7\%) considerados incluídos nesta revisão. Tais artigos tratam diretamente sobre a questão do racismo e sua relação com o desenvolvimento econômico.

\section{Principais argumentos dos artigos selecionados}

Para o conhecimento desses artigos, sintetizamos seus principais argumentos da questão racial de acordo com os "três limites" para o desenvolvimento econômico-social, abordados por Ianni e Fernandes (ver cuadro 1). 


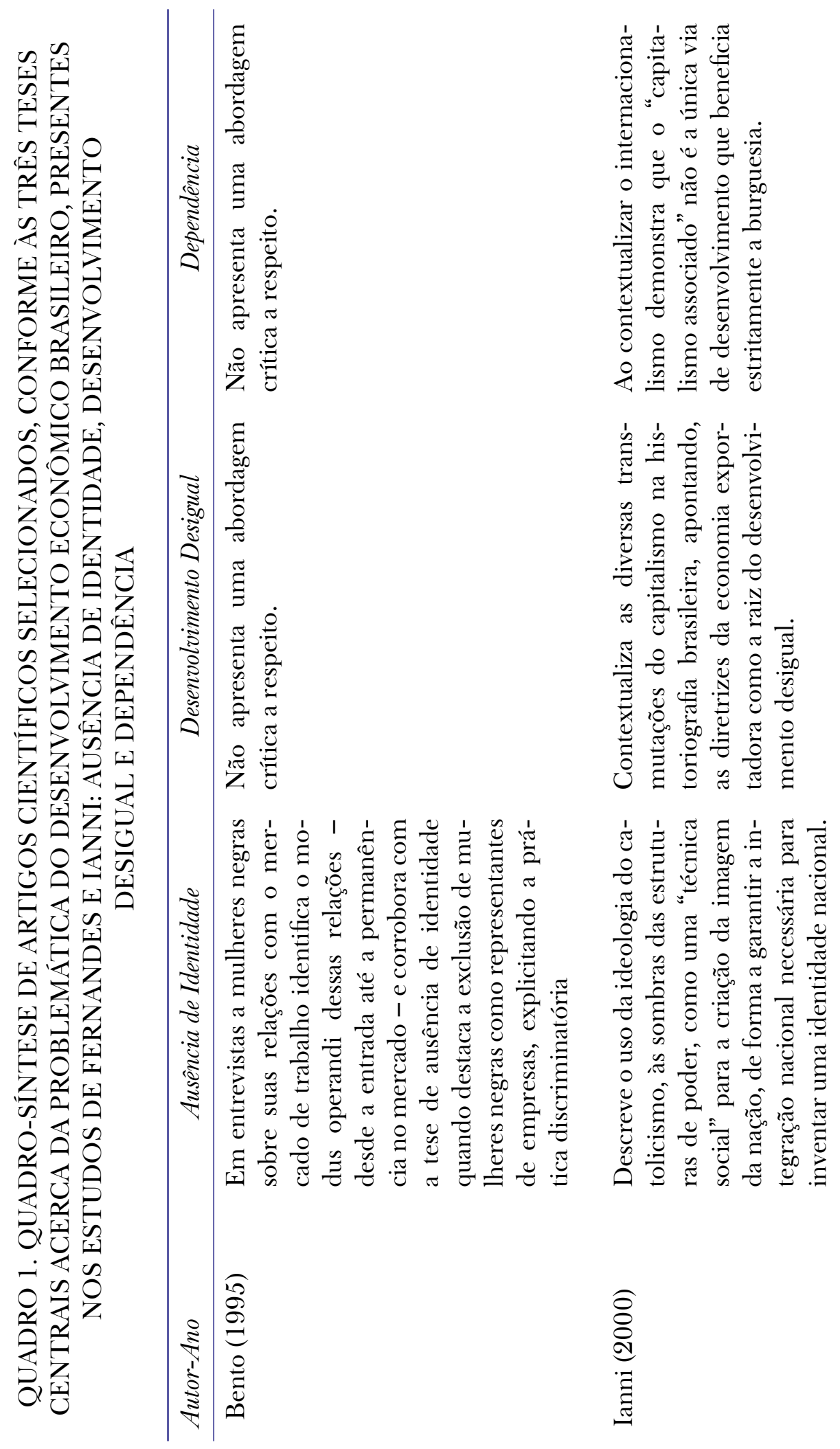




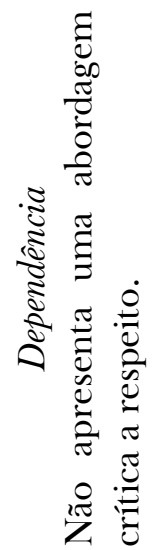

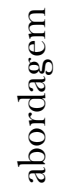

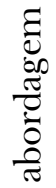

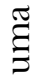

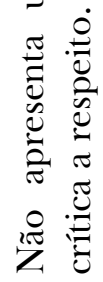

$\stackrel{\pi}{\Xi}$
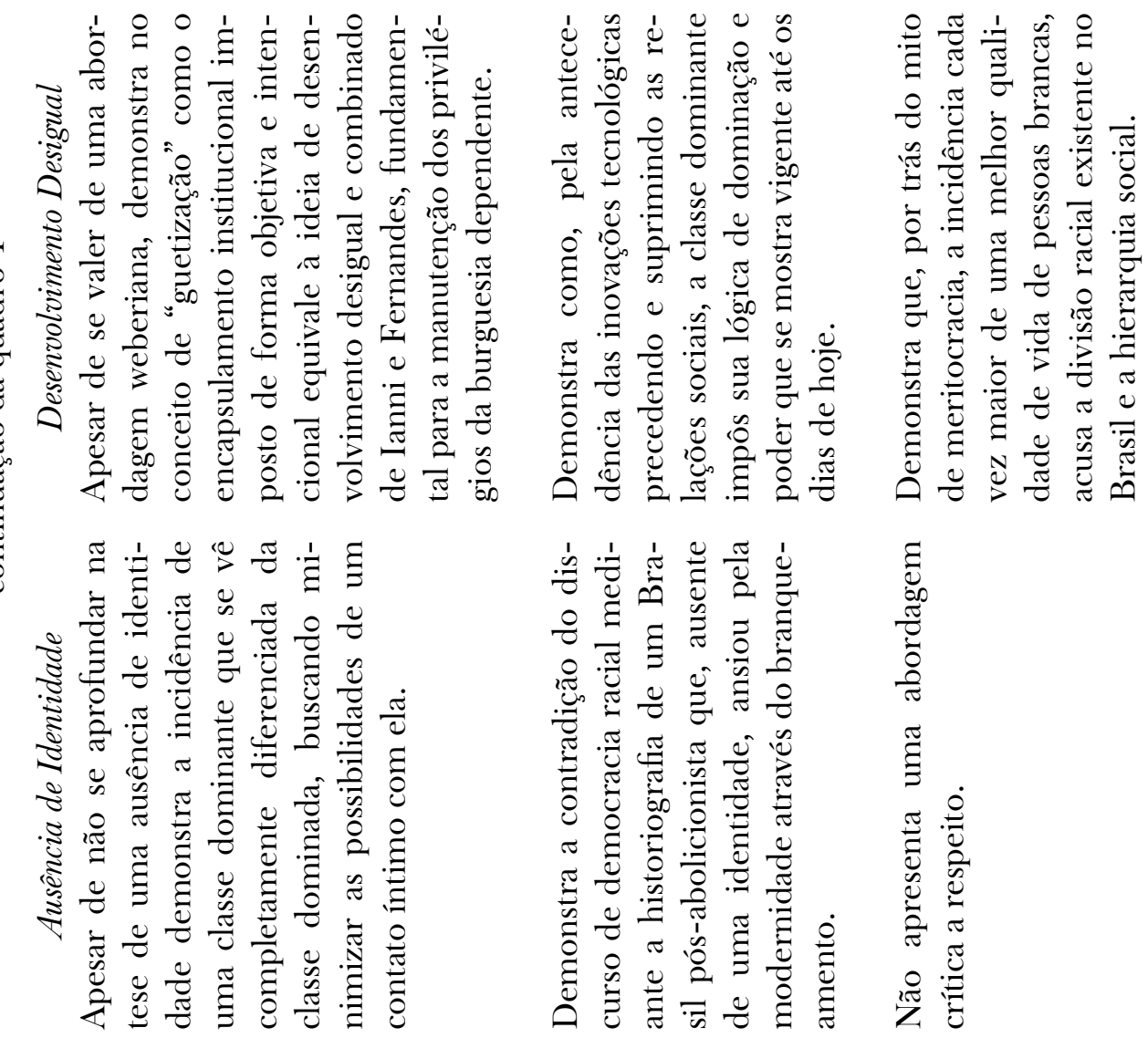

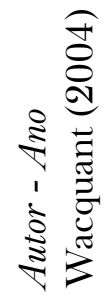

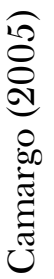

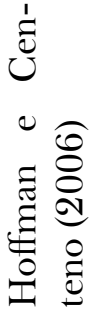



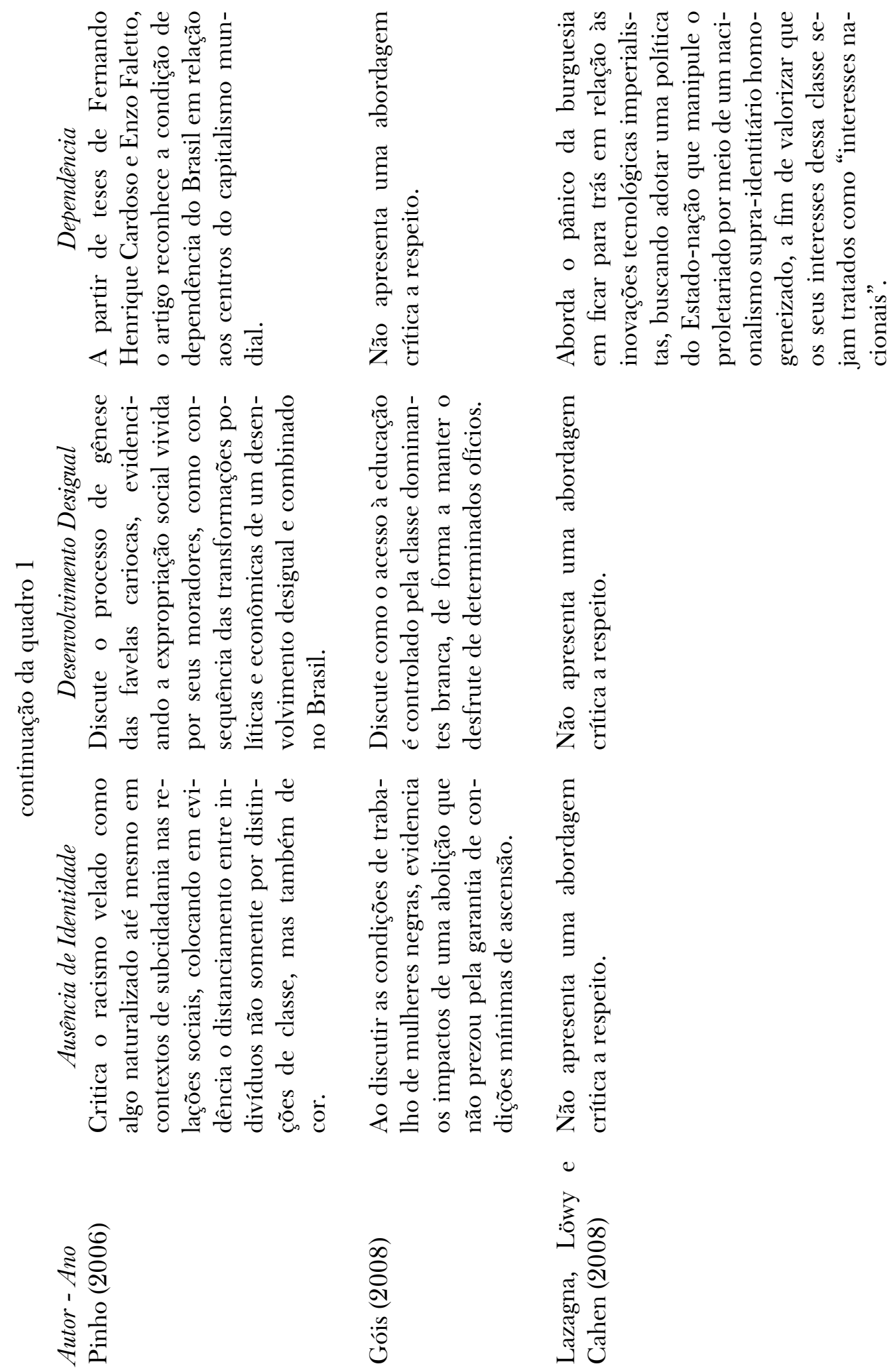

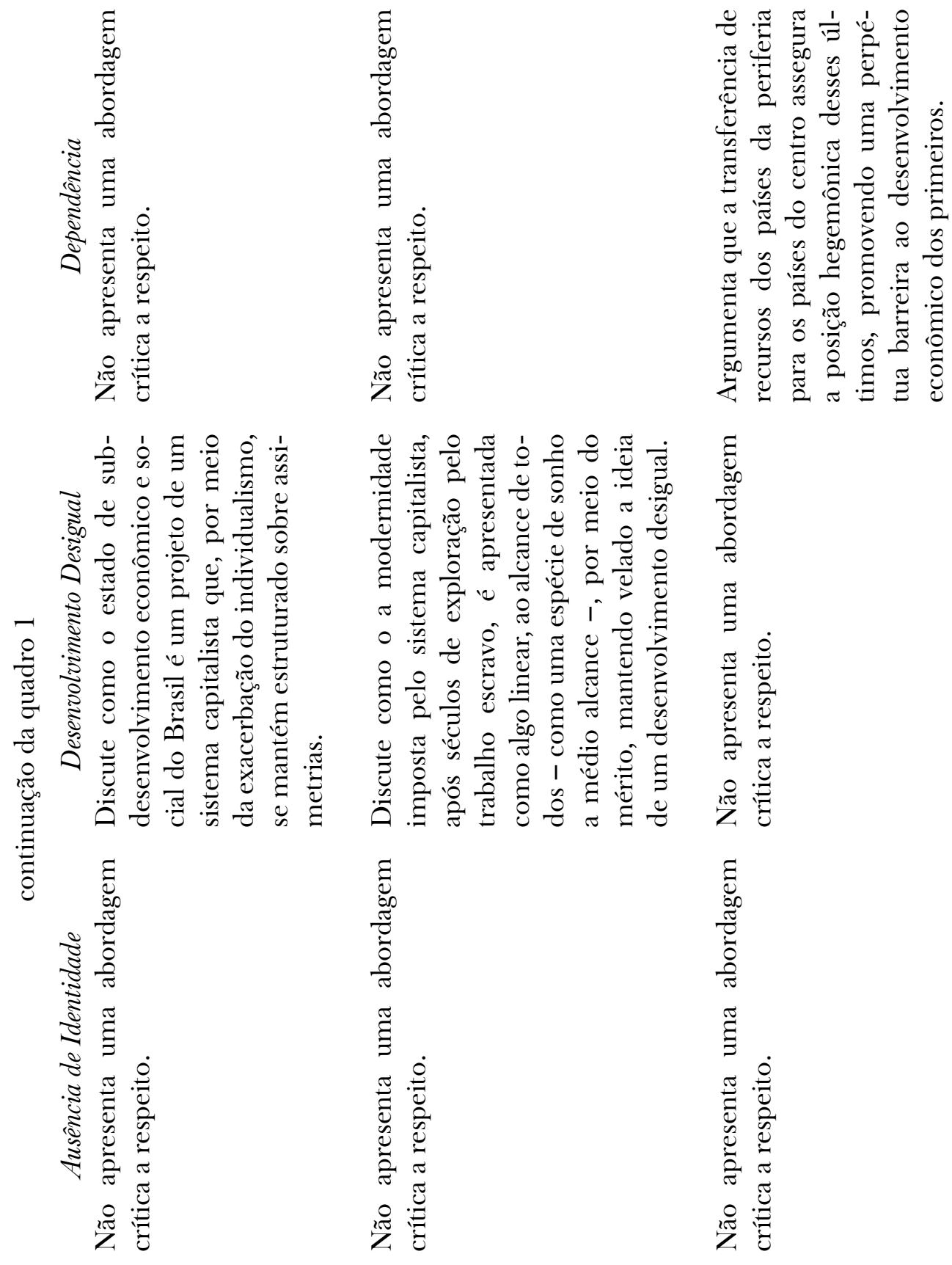

$\underset{\Xi}{\Xi}$

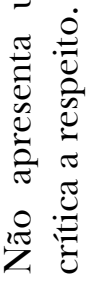

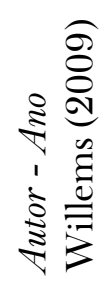

$\stackrel{1}{\mathrm{~N}}$

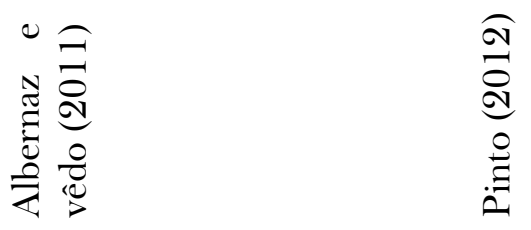



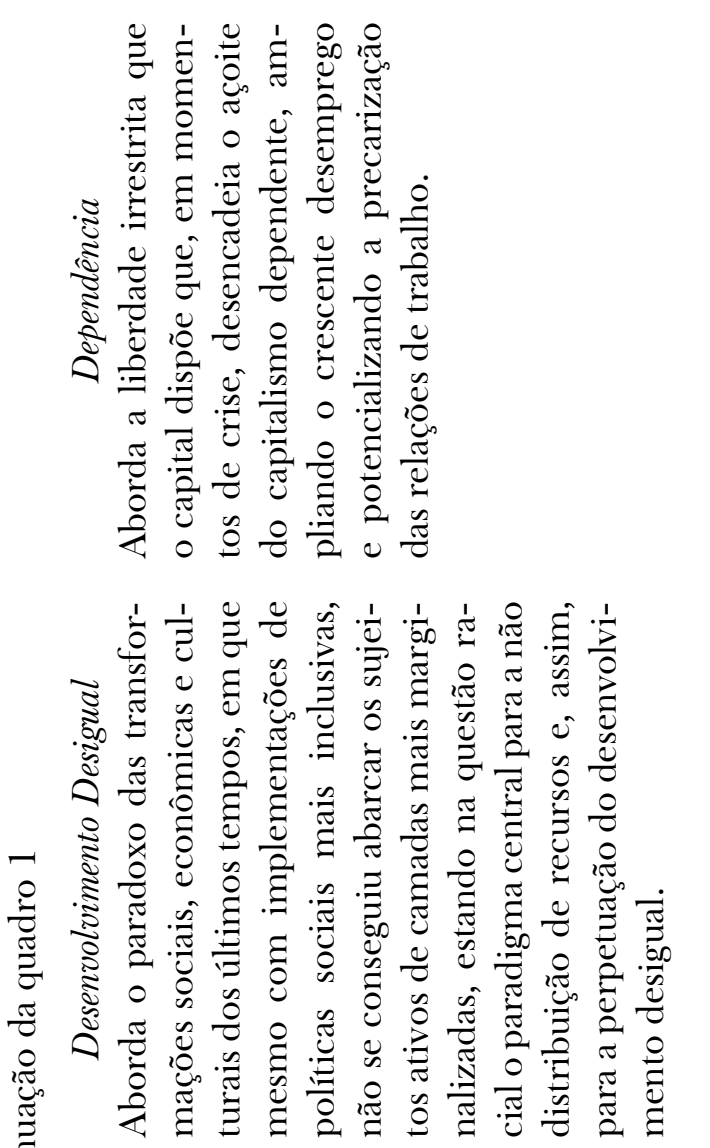

Ð
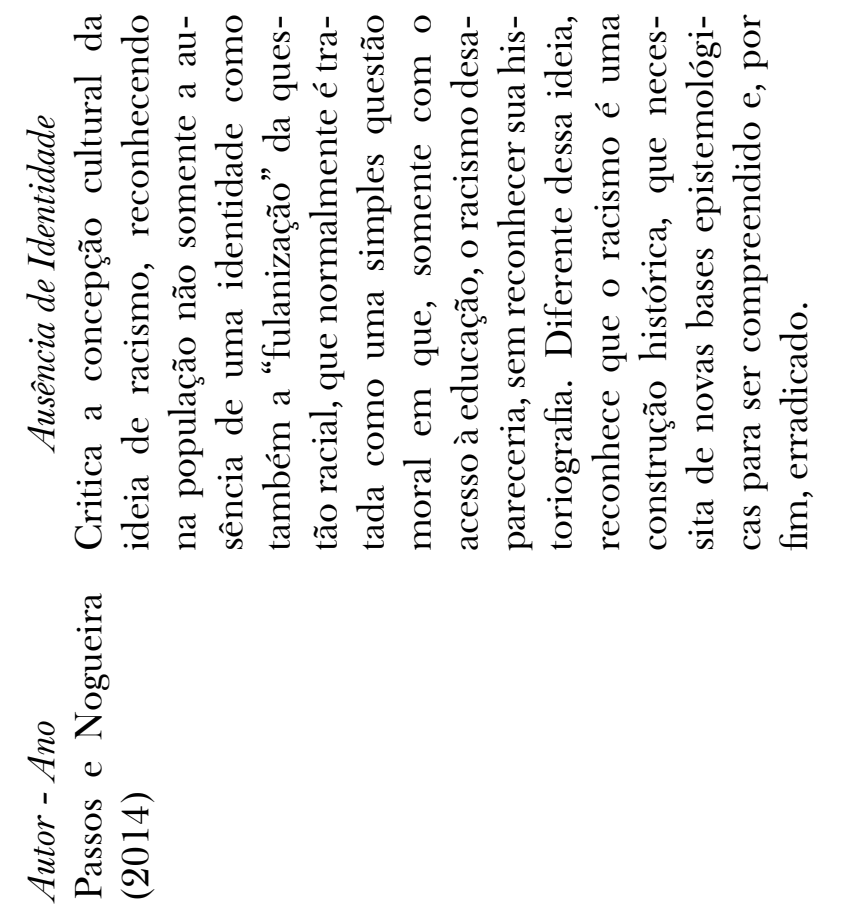

$\Xi$
0
0
0
0
0
0
0

$\Xi$
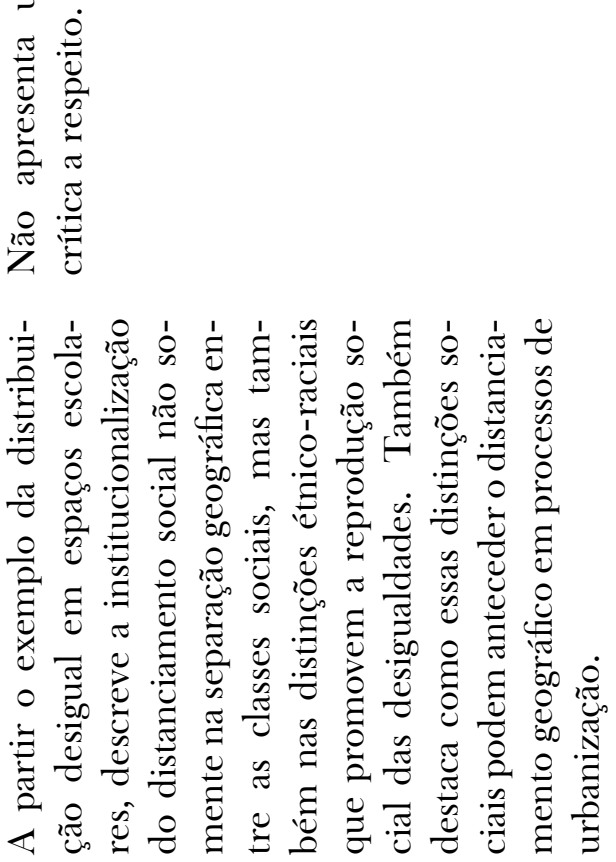

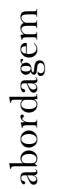

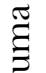

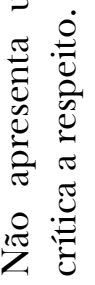

$\stackrel{0}{\underline{2}}$

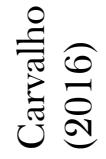



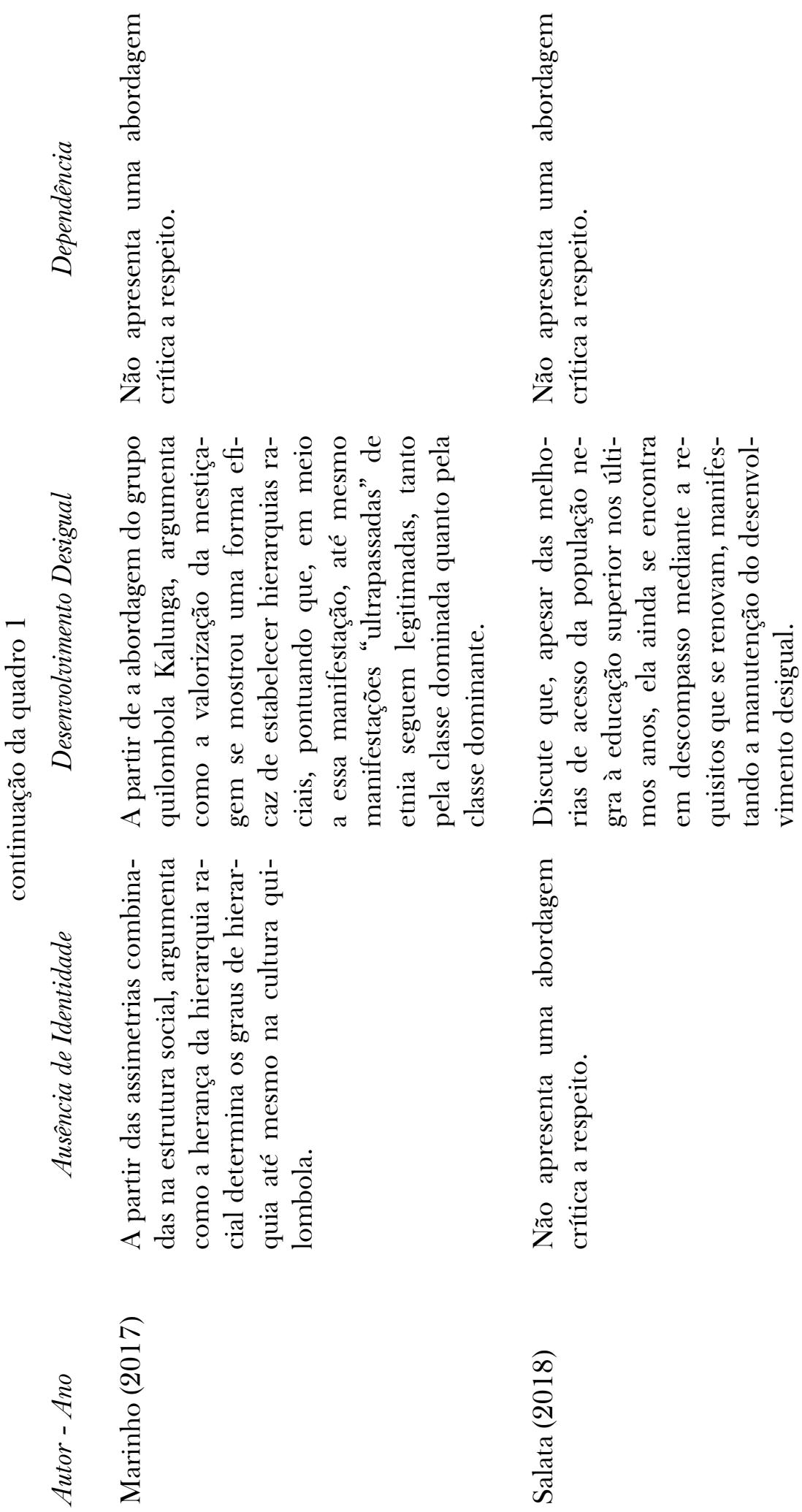

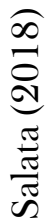

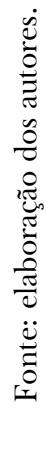


A partir dos argumentos gerais dos artigos incluídos nesta revisão sobre a questão racial e o desenvolvimento, buscamos discuti-los à luz da contribuição de Ianni e Fernandes, o que é realizado na próxima seção. Ressaltamos que esses artigos, ainda que apresentem tempos de publicação posteriores distintos, a intenção era identificar até que ponto as temáticas originalmente abordadas por Ianni e Fernandes se mantém ou se modificaram ao revisarmos a literatura mais recente.

Salientamos ainda que para a discussão da próxima seção, nossa intenção não foi identificar em que tradição teórica-epistemológica os autores dos 15 artigos se apoiam. Na realidade, optamos por identificar o quê da tradição marxista de Ianni e Fernandes foi incorporado por esses autores nas suas diversas matrizes epistêmicas.

\section{O DESENVOLVIMENTO E O PESO DA QUESTÃO RACIAL À LUZ DAS CONVERGÊNCIAS E DIVERGÊNCIAS DA LITERATURA MAIS RECENTE COM OS CLÁSSICOS DE IANNI E FERNANDES}

\section{A questão racial na ausência de identidade: a persistente contradição modernista}

Os interesses por trás da compreensão do Brasil, ao longo do século xx, em meio à busca por uma maior aproximação dos padrões estabelecidos pelos países de centro do imperialismo, e em concomitância com a dualidade valorização-extermínio de minuciosas particularidades da formação social brasileira, foram guiados estritamente pela redutível e autoritária ideia de que "o povo, enquanto coletividade de cidadãos, precisa ser criado e tutelado, de cima para baixo" (Ianni, 2000, p. 58).

Neste panorama historiográfico, diante da inadequação do Brasil ao ritmo do modelo de desenvolvimento que lhe foi imposto pela burguesia, e em concordância com a tese de Florestan Fernandes, destacamos como uma das razões para o atraso em seu desenvolvimento econômico e social a ausência de identidade proveniente do fascínio pela modernidade. Dialogando com a tese de Fernandes, o antropólogo Osmundo de Araújo Pinho argumenta que o Brasil não realizou a transição para a modernidade de forma eficaz pela razão de que "não teríamos sido capazes de institucionalizar os valores modernistas [...] em função de nosso dualismo estrutural” (Pinho, 2006, p. 177). Em consonância, o historiador Geraldo Leão Veiga de Camargo demonstra que o modernismo brasileiro -marcado pela Semana de Arte Moderna, de 1922- implementou uma radicalização estética (completamente subordinada aos ares políticos de sua época) por meio de soluções visuais, que eram: “(...) destinadas ao mesmo tempo a apresentar ares de modernidade e atualização artística e cumprir o papel social que as doutrinas políticas sugeriam, levaram a um conjunto de formulações estéticas, cujas características permaneceram influentes por muito tempo" (Camargo, 2005, p. 68).

Camargo, tomando como exemplo a interpretação da modernidade, sob o ponto de vista do realismo russo dos anos 1920, define a modernidade não como algo determinado pelas inovações tecnológicas por si, mas, particularmente, como algo determinado pelas relações entre classes, com a "[...] transformação tecnológica seguida a partir das relações sociais e não ao contrário" (Camargo, 2005, p. 67).

Um dos aspectos da modernidade, disposto em concomitância com a queda do regime de trabalho escravo, foi o discurso meritocrático de revalorização do trabalho. A ânsia por trás desse discurso burguês dependente se apoia na questão racial, a partir de o fértil e duradouro mito da democracia racial, e, em seu trabalho mais recente, Ianni mantém a argumentação de que a lógica de sua narrativa é “tomada principalmente em termos do contraponto 'negros e brancos' na 
formação e dinâmica da sociedade brasileira” (Ianni, 2000, p. 68). A dualidade desse pensamento permeia as relações sociais e se reflete drasticamente em diversos mitos e falácias que afetam as relações econômicas do Brasil. É importante destacar que, da mesma forma que o trabalho foi revalorizado, a miscigenação também necessitou ser valorizada pois, conforme define a historiadora Thais Alves Marinho, tanto quanto a revalorização do trabalho é fundamental para a implementação e manutenção do sistema capitalista, "a valorização da mestiçagem é a forma tradicional de se processarem as relações raciais” (Bento en Marinho, 2017, p. 366).

Com a ideologia racial da burguesia dependente (majoritariamente branca) vigente, muitos dos atributos da escravidão seguem apenas com uma nova roupagem, determinando espaços, estereótipos, hierarquias sociais e relações econômicas. Camargo, tomando como exemplo a iconoclastia de Portinari em representar pessoas negras em suas obras, destaca que o realismo de tais obras, em seu contexto histórico, fazia oposição à idealização que o governo Vargas fazia do Brasil, o qual, na prática, “[...] excluía, por exemplo, a representação de negros em obras de arte que fossem enviadas para o exterior" (Camargo, 2005, p. 71).

Conforme vimos na primeira seção deste estudo, a partir da contribuição dos autores Ianni e Fernandes, a predominância dessas assimetrias provém, em grande parte, da negligência acerca da questão racial por parte de uma nação que não tem uma identidade própria e que, pela condição de subordinação a uma burguesia dependente, sucumbe a interesses externos. Em observação a esse ponto Marinho (2017) demonstra que, na praxe da ideologia racial, é comum encontrar, de forma implícita ou explícita, manifestações ultrapassadas de etnia, que generalizam, desrespeitam nossa diversidade cultural e suprimem pautas identitárias e as reduzem a questões de exclusão social generalizadas e pouco aprofundadas -como é o exemplo da comunidade remanescente de quilombo, denominada Kalunga. Em observação ao posicionamento do jornalista e professor universitário Joãomar Carvalho de Britto Neto, Marinho argumenta que:

Em sua tese de doutorado, defendida na França, apresenta a ideia de que a única singularidade dos Kalunga é o fato de terem sido tratados como "etnicamente especiais", já que nunca estiveram isolados (ele adota uma concepção ultrapassada de etnia, segundo a qual o isolamento e a cultura original seriam critérios para o estatuto étnico). Tampouco, segundo ele, apresentam vínculos com a cultura africana, tratando-se de brasileiros comuns, marcados pela exclusão social, como tantos outros grupos brasileiros (Marinho, 2017, p. 357).

Em seu artigo, Marinho demonstra como opositores, alienados à ideologia racial, buscam desregulamentar a ocupação fundiária dos quilombolas, sob a justificativa de inconstitucionalidade, por não os interpretar como um povo com uma cultura própria e também por não interpretarem o Brasil como uma nação plural. A pressão que os Kalunga recebem fez com que: "[...] uma concepção essencialista, culturalista e pragmática de identidade fosse adotada [...], a fim de fazer valer o seu direito ao território e justificar o reconhecimento de sua contribuição à sociedade brasileira" (Marinho, 2017, p. 357).

Por trás das romantizações do mito da democracia racial, o que se vê na prática é a imposição de padrões culturais que moldam e delimitam as relações de poder no meio social -e um exemplo prático disso é o fato de que a herança racista e a ideologia racial do branqueamento ${ }^{3}$ tiveram

${ }^{3}$ Em se tratando de Américas, Jacobson (1999) aponta que a categoria "branqueamento" é dotada de uma instabilidade monolítica já que a "certeza" na desigualdade racial reforça um regime de conhecimento racial que subjaz o branqueamento aos imperativos conflitantes de uma economia capitalista e uma cultura política democrática que se estabeleceu 
tanta força no Brasil que "[...] geraram situações em que a cor mais clara é tida como vantajosa em várias regiões da comunidade Kalunga” (Marinho, 2017, p. 366). Corroborando com a tese de ausência de identidade, Camargo adverte, ainda, que essa dissociação advém de uma profunda negligencia a respeito de nossa historiografia por parte da burguesia que, através de esculturas e monumentos públicos, preserva a "lógica do poder vigente, para difusão e fixação de seus pontos de vista" (Camargo, 2005, p. 63) -o que torna a desconstrução desses padrões e uma real equidade algo cada vez mais distante.

Na problemática da transformação da população de trabalhadores em povo, vista nos estudos de Ianni, o assistente social João Bôsco Hora Góis utiliza como exemplo as mulheres negras, que -neste caso, tanto quanto os homens negros- "[...] não conseguiram alterar de modo pleno o seu status no mundo do trabalho" (Góis, 2008, p. 750), e, não sendo salvaguardadas as condições mínimas para ascensão, esse fato foi determinante para que a maior parte da população pobre e em situação de miséria fosse composta por pessoas negras.

A não identificação da burguesia com a população proletária (majoritariamente não branca), dentro de uma nação da qual sua totalidade não pode ser representada por suas partes e que, segundo Fernandes, tem como forte característica o caráter de destruição identitária, faz com que a violência advinda das classes dominantes -que usam o Estado a seu favor- seja mais facilmente aplicada direta ou indiretamente. $\mathrm{O}$ uso do poder da polícia é a expressão da violência direta. Diante da natureza exclusivista da burguesia dominante, o sociólogo francês Loïc Wacquant, apesar de trazer a abordagem weberiana de "cercamento excludente", corrobora com a tese de Fernandes, ao sugerir que o gueto não seja necessariamente estudado com total enfoque às favelas ou bairros de classe baixa, mas sim “às reservas, aos campos de refugiados e à prisão, pertencendo assim a uma categoria maior de instituições de confinamento forçado de grupos despossuídos e desonrados" (Wacquant, 2004, p. 162).

Dessa forma, à luz dos artigos mais recentes, é possível reafirmar que a expressão cultural dessa ausência de identidade é, intrinsecamente, a expressão da prática segregacionista do imperialismo -o que nos leva de imediato à outra prática desse sistema para a manutenção de seu poder: o intencional desenvolvimento desigual e combinado.

\section{A questão racial e o desenvolvimento desigual: sofisticação da escravidão}

Segundo a tese de Fernandes, uma das características mais marcantes da burguesia, para que se atinja o equilíbrio necessário para o desfrute do mínimo de estabilidade em benefício próprio dentro do capitalismo dependente, é manter, de forma proposital, um sistema produtivo heterogêneo com suas diversas fases coexistindo. A existência de classes sociais -especialmente tão distantes-, segundo o artigo mais recente de Octávio Ianni, é dada pela razão de que: "no século xx, a sociedade brasileira combina a estrutura e dinâmica de classes sociais com os remanescentes de castas. Há formas de sociabilidade, etiquetas de relações raciais, padrões de organização da

diferentemente ao longo das Américas. Assim, para exemplificar, Appelbaum (1999) ao dar o exemplo da construção racial do "Antioqueño", na Colombia, o branqueamento dos povos na região cafeeira da qual faz parte ilustra algumas das maneiras como os colombianos do século XIX organizaram a hierarquia racial em seu espaço nacional. Eles criaram uma geografia inter-regional de raça e status que privilegiou certos lugares e povos dentro da nação como brancos, modernos e progressistas, enquanto denegria outros como atrasados e inferiores. 
família, trabalho, associações, vizinhanças, escolas, igrejas, clubes e outras instituições nas quais manifestam-se traços remanescentes de castas mesclados com as práticas das relações de classes” (Ianni, 2000, p. 67).

Portanto, manter as etiquetas e principalmente o lugar de ocupação de cada indivíduo, conforme argumenta Ianni (2000), é de grande importância para manter os privilégios ofertados por essa estrutura, que mantém vigente esse modelo de desenvolvimento desigual e combinado. A psicóloga Maria Aparecida Silva Bento, com enfoque na questão da mulher negra (na qual ela traz, em concomitância, uma abordagem de raça e gênero), exemplifica a praxe dessas etiquetas em uma situação: "Embora nem sempre as empresas e seus representantes explicitem seus critérios raciais, esse tipo de prática discriminatória no ambiente de trabalho ocorre de maneira sistemática e determina a dramática situação de vida da mulher negra hoje” (Bento, 1995, p. 484).

A compreensão da divisão desses espaços no Brasil, especificamente em relação à população negra, pode ser dada pelo conceito de "guetização", utilizado por Wacquant, que, ao definir a ideia de gueto em quatro elementos básicos - "o estigma, o limite, o confinamento espacial e o encapsulamento institucional” (Wacquant, 2004, p. 157)-, adverte que sua definição não deve se confundir com a ideia simplista de uma área isolada pelo processo histórico da colonização, mas sim como, objetiva e intencionalmente, "[...] uma forma especial de violência coletiva concretizada no espaço urbano” (Wacquant, 2004, p. 158). Para Wacquant, não necessariamente a carência de recursos representa a ideia metafórica que se tem de gueto. A título de exemplo, o autor ainda aponta que a consideração da guetização como uma mera manifestação da natureza humana proveniente da colonização-, na verdade, é uma violência coletiva expressa em um espaço urbano e, como tal, "[...] uma forma muito peculiar de urbanização modificada por relações assimétricas de poder entre grupos etnoraciais" (Wacquant, 2004, p. 158). Portanto, é importante destacar que a guetização da população negra existente no Brasil funciona como uma ferramenta de cercamento etno-racial corrobora com o regime de classes imperialista e, objetivamente, amplifica o modelo de desenvolvimento desigual vigente no país - o que, apesar de ser reconhecido pelo autor em termos não marxistas, converge com a argumentação de Fernandes e Ianni.

Funcionando como uma ferramenta de transferência de renda às avessas em favor desta burguesia, a superexploração da força de trabalho é usada para amortecer os impactos das inovações tecnológicas dos países de centro, mantendo o trabalhador, quando não completamente afastado dos meios de produção, sob total controle ${ }^{4}$ e sem chances de progredir. A filósofa e doutora em direito Renata Ovenhausen Albernaz, e o sociólogo político Ariston Azevêdo corroboram com a argumentação de Ianni no reconhecimento de que há um "mito da neutralidade" acerca do projeto

\footnotetext{
${ }^{4}$ Por sua vez, cabe mencionar os argumentos de Quijano (2005) sobre a forma específica dos mecanismos de controle e de exploração do trabalho na história latino-americana que incorpora a escravidão. Segundo esse autor, "todas as formas de controle e de exploração do trabalho e de controle da produção-apropriação-distribuição de produtos foram articuladas em torno da relação capital-salário (de agora em diante capital) e do mercado mundial. Incluíram-se a escravidão, a servidão, a pequena produção mercantil, a reciprocidade e o salário"(p. 118). Nessa perspectiva do capitalismo em nível mundial e sua forma de atuação na América Latina deve ser acrescentada a importante contribuição de Wallerstein (1979,1984 e 1998). De acordo com esse autor, o moderno sistema mundial corresponde a combinação entre a economia-mundo capitalista, seus fluxos de capitais e mercadorias, e a superestrutura que lhe assegura o controle do poder político, particularmente o sistema inter-estatal. Para Wallerstein, a gênese da estrutura de poder do capitalismo se dá desde o século Xvı com a construção de uma economia euro-americana. Através dela libertou as trocas de longa distância dos custos políticos exigidos pelos impérios, ampliou o mercado mundial para incluir a oferta de suprimentos básicos à Europa Ocidental e criou uma estrutura econômica de monopólios, direcionada para a obtenção do superlucro. Toda essa estrutura desenvolveu o sistema inter-estatal, a partir do século xVII, como o eixo de uma superestrutura jurídico-política para o protagonismo do capital e sua mundialização.
} 
de modernização das nações imperialistas -especialmente o modo pelo qual foi feito: após séculos de exploração dentro de uma relação de trabalho escravocrata, "[...] impondo a modernidade europeia enquanto novo paradigma universal de vida cotidiana, de compreensão da história, da ciência e da religião; e econômico" (Albernaz e Azevêdo, 2011, p. 333). Com base nessa superexploração, o modelo de desenvolvimento desigual mantém à disposição da burguesia uma grande massa de trabalhadores ociosos. Wacquant define o uso sócio-organizacional do gueto como uma ferramenta que: "usa o espaço com o fim de conciliar dois objetivos antinômicos: maximizar os lucros materiais extraídos de um grupo visto como pervertido e perversor e minimizar o contato íntimo com seus membros, a fim de evitar a ameaça de corrosão simbólica e de contágio (Wacquant, 2004, p. 157).

Pagando sempre o maior preço pela perpetuação dos privilégios da burguesia, as teses de Fernandes e Ianni demonstram que a população negra está condenada à não ascensão. Na prática, ocorre que as benesses e privilégios são todos promovidos direta ou indiretamente pela disposição do capital: desde o acesso à educação até o estabelecimento de contatos em espaços específicos. Ainda, quando a pessoa negra consegue ter acesso a um espaço de ascensão, há uma imensa barreira na questão da interação (desde a ausência de um mesmo leque cultural até a incidência de manifestações veladas de racismo -que, mesmo quando não intencionais, geram segregação). Confirmando essa demonstração, o cientista social José Lopes Carvalho Filho descreve segregação não somente como uma separação espacial, mas também como "uma forma institucionalizada de distância social [...] intrinsecamente ligada ao debate ideológico" (Carvalho Filho, 2016, p. 365). $\mathrm{O}$ autor destaca que, em uma visão sociológica, o estudo dos processos de segregação:

necessita desvelar os jogos e disputas que estão por trás das razões das escolhas das experiências escolares das famílias. Embora não se proponha uma ciência social total, no campo da educação, esta perspectiva de análise suscita um olhar global sobre os fatores econômicos, culturais, mas também, as distribuições desiguais nos espaços escolares fundadas nas diferenciações de gêneros e étnico-raciais que vêm a lume com o processo de democratização do ensino em termos de acesso e prolongamento dos estudos (Carvalho Filho, 2016, p. 377).

Os autores Passos e Nogueira (2014), da mesma forma que demonstra Ianni, argumentam que existe uma noção familiar de que o racismo é uma construção ideológica, pendendo a uma questão moral evitável com acesso à educação. No entanto, eles ressaltam que essa é uma concepção errônea, pois “[...] o racismo teria sido construído historicamente, e não ideologicamente" (Moore en Passos e Nogueira, 2014, p. 107) -indo além de uma simples questão semântica, reivindicando por uma renovação nas bases epistemológicas para sua compreensão.

No ambiente educacional as barreiras mais significativas se manifestam na entrada e na permanência nesses espaços, reforçando, desta forma, o intencional desenvolvimento desigual descrito por Fernandes e Ianni. O cientista social André Salata demonstra que, quanto mais forte a relação entre a origem social de um indivíduo e o nível de escolaridade, menores são as oportunidades de ascensão e maiores as "[...] vantagens dos indivíduos provenientes de famílias mais privilegiadas" (Salata, 2018, p. 221). Em seu estudo, dentre as hipóteses levantadas, Salata, reconhece as disparidades ao citar a hipótese da Desigualdade Maximamente Mantida (Maximaly Maintained Inequality -MMI), de autoria de Raftery e Hout (1993), que tem como postulado básico a ideia de que uma expansão educacional generalizada irá apenas beneficiar o grupo melhor preparado, 
mantendo inertes as chances de acesso da classe mais carente -o que o leva a concluir que, caso o grupo em desvantagem não receba algum tipo de auxílio equitativo "[...] as desvantagens relativas permanecerão constantes" (Salata, 2018, p. 223).

No que condiz ao acesso à educação, o cientista social e economista Juarez Lopes de Carvalho Filho destaca, por meio da sociologia da distribuição espacial e social dos estabelecimentos de ensino -conceito que investiga a relação entre família e instituição escolar a partir de a constatação de que famílias privilegiadas têm o poder de optar por uma escolarização amplamente mais favorecida, assim preparando seus filhos para posições privilegiadas na sociedade-, como a escola assume o papel de um importante agente no processo de "[...] reprodução social das desigualdades de acesso à escolarização" (Carvalho Filho, 2016, p. 362), mantendo, desta forma, o modelo de desenvolvimento desigual. Ainda, no que condiz a questão da permanência nos espaços, é importante destacar que o ambiente escolar tem o poder de promover concorrência entre os agentes e, dessa forma, o autor demonstra que a posição de um agente no espaço lhe concerne o poder de se apropriar deste -portanto, "[...] se existem condições sociais, econômicas e culturais de apropriação do espaço urbano, é necessário reconhecer que o espaço é possuído pelos agentes sociais em proporção de seus recursos econômicos e culturais" (Carvalho Filho, 2016, p. 376).

O regime de classes, de acordo com a teoria de Fernandes e Ianni, tem como modus operandi econômico e social do acúmulo de poder burguês, se valendo do racismo como uma ferramenta eficaz para sua perpetuação e, portanto, o recriando constantemente (não é de interesse do capital erradicá-lo). A manutenção do privilégio é dada pelo fato do capital se sobressair ao trabalho e pelo status quo do trabalho assalariado promovido pelo sistema capitalista. Desta forma, Osmundo Pinho argumenta:

Ora, a questão da modernização desigual brasileira parece inextricavelmente associada ao problema racial -basta lembrarmos como a Escola de Sociologia Paulista e os estudos da UNESCO colocaram a questão. O 'problema racial' brasileiro seria um aspecto da demora cultural, ou um resíduo, símbolo do atraso e do passado, com existência social asfixiada pelo progresso, pela evolução do capitalismo e da sociedade de classes, em suma, pela modernização. No limiar do século XXI parece ter ficado claro, entretanto, que a tão esperada modernização já chegou e ela não significou a redenção de sujeitos sociais racializados, nem dos pobres, nem da exclusão social, ou a redução da violência endêmica, como uma pacificação social. A modernização da estrutura social não poderia ser outra coisa que não também a modernização dos agentes sociais. Ou a formação de sujeitos sociais modernos, dotados de subjetividade e racionalidade modernas (Pinho, 2006, pp. 177-178).

De acordo com as teses de Fernandes e Ianni, a sociedade que sucedeu o regime escravista manteve, através de camadas sociais, muitas das mesmas assimetrias que eram vigentes. Camargo, em citação à antropóloga Lilia Schwarcz, demonstra que a inserção da população negra no modelo de sociedade moderno, no início do século xx, passou por vários debates que colocavam em questão as contradições provenientes do contraste entre o discurso racial com questões básicas e fundamentais de cidadania, "[...] já que no interior desses novos modelos discorria-se mais sobre as determinações do grupo biológico do que sobre o arbítrio do indivíduo" (Schwarcz en Camargo, 2005, p. 69). O trabalhador negro é prejudicado até os dias de hoje por diversas falácias que perpassaram esse período e, na não solução desse debate, segue negligenciado das mais variadas 
formas no mercado de trabalho capitalista. Se tratando, ainda, do processo de ascensão do negro ao longo dos anos -a começar pelo recém-liberto- Cardoso aponta em sua pesquisa que ele "[...] era regulado pela fidelidade dos 'cidadãos' aos chefes de parentelas poderosas" (Cardoso en Pinho, 2006, p. 180).

Dentre os artifícios mais frequentes usados pela burguesia para manter o desenvolvimento desigual se destaca o argumento da meritocracia, que, guiada por um senso moralista, é usada como justificativa para a extrema intolerância diante de possíveis reivindicações e para manter as assimetrias. Com o olhar de "fatalidade" para tais questões, a burguesia, incapaz de ver essas assimetrias, aponta como únicas soluções o assistencialismo ou a criminalização -soluções estas que não estão livres de valores escravocratas. É possível afirmar que as penitenciárias, majoritariamente ocupadas por negros, são uma continuação da escravidão, diante da constatação de que:

Na média, os brancos vivem sete anos mais, têm um quarto a mais de chances de sobreviver na infância, sua taxa de conclusão da escola secundária é quatro vezes maior e têm metade das chances de serem presos (Fry, Lovell e Wood, en Hoffman e Centeno, 2006, p. 28).

Após a abolição, conforme demonstrou Ianni (2000), algumas problemáticas sociais, muito vagarosamente, foram tratadas como problemas políticos ao invés de problemas de polícia, mas isso não foi feito em ritmo e intensidade suficientes para modificar a estrutura das relações econômicas e sociais do país. Com a vigência de desigualdades manifestadas na fome, falta de habitação, carência nas condições de saúde e acesso precário à educação, é possível afirmar seguramente que não houve uma mudança estrutural significativa no pós-abolição.

No que tange a falta de habitação, descrita por Fernandes e Ianni como consequência de uma abolição negligente, a incidência de pessoas negras nas ruas -em especial homens-é encarada com a mesma naturalidade de elementos arquitetônicos neutros. A habitação nas grandes cidades pode ser encarada como um reflexo direto da acessibilidade aos meios de produção, em que, quanto mais distante dos centros urbanos um indivíduo reside, maiores são as chances de sua segregação não ser somente espacial (mas sim dos meios de conseguir ascender). Complementando essa argumentação, Carvalho Filho descreve o exemplo de que, a classe proletária está sujeita ao constante risco da especulação imobiliária - visto que “[...] o processo de segregação é impactado pelas políticas de urbanização, como a destruição de bairros populares, e o aumento do aluguel pressiona as famílias de classe popular a se deslocarem para a periferia" (Carvalho Filho, 2016, p. 367).

No acesso à educação superior, apesar de algumas melhorias nos últimos anos - "se, em 1995, o fato de ser negro reduzia essas chances em 59\%, em 2015 essa desvantagem ficava em 41\%” (Salata, 2018, p. 231) -a população negra ainda se encontra bastante defasada, visto que- em consonância à teoria de Fernandes e Ianni, o mercado de trabalho exige cada vez mais requisitos que, muito além do ensino superior, estão cada vez mais distantes de serem obtidos pela população negra e pobre. Tais desigualdades são fomentadas e exacerbadas pelo desenvolvimento desigual promovido pelo sistema capitalista. É importante destacar que o acesso à educação também pode ser medido por meio de elementos organizadores de trajetória, visto que a escolha por determinada área é dada à população mais carente "[...] pela leitura que têm das suas possibilidades de bom desempenho no vestibular e [...] pelo cálculo das dificuldades que teriam em manter-se" (Góis, 2008, p. 749) nos estudos -tanto por questão de tempo disponível quanto pelos custos.

A causa maior do estado de subdesenvolvimento do Brasil, além da visão apequenada por trás do interesse exacerbado no enriquecimento próprio, descrito por Fernandes, é justamente a aversão das burguesias a transformações sociais profundas. O antropólogo e sociólogo Emílio Willems aponta como características intrínsecas do capitalismo: "necessidades ilimitadas, sistema monetá- 
rio e individualismo" (Willems, 2009, p. 207). Portanto, interessa às burguesias desfrutar do desenvolvimento dos países imperialistas enquanto mantêm a história do próprio país congelada com formas sofisticadas de escravidão.

A questão racial e a dependência: contradição etnocentrismo e consumismo 'de cor'

No que condiz a argumentação da dependência, a cientista política Simone Rodrigues Pinto apresenta o argumento de que o centro e a periferia compõem um sistema global no qual as características originárias foram expostas por Lênin -que descrevia o imperialismo como uma fase superior do sistema capitalista, afirmando que "neste mundo, em que o sistema econômico é único, as economias subdesenvolvidas se articulam com o sistema econômico mundial mediante a transferência de recursos da periferia para o centro" (Pinto, 2012, p. 352).

Ao longo de sua história o Brasil seguiu e continua seguindo a influência de interesses externos, que normalmente são legitimados internamente de cima para baixo, justamente pela burguesia dependente, majoritariamente branca e com pouco tato para questões sociais tão aprofundadas como a do preconceito de cor. Ianni (2000) observa que o poder monárquico português (com aval do poder monárquico britânico) legitimou o estado-nação e os governantes do que se tornou "Brasil", e também observa que a participação ativa do imperialismo inglês influencia ao longo de toda a história de forma decisiva nos "[...] laços econômico-financeiros e institucionais indispensáveis à formação e consolidação do estado nacional” (Ianni, 2000, p. 66).

Fernandes e Ianni demonstram que a sucessão de ciclos da economia exportadora, entre os século xvı e xx, foi estruturando um desenvolvimento desigual no Brasil -do qual a industrialização veio de forma a acentuar as desigualdade sobre regiões povoadas em prol de interesses externos. Em relação a isso, Osmundo Pinho argumenta que, nesse modelo de sociedade, o 'moderno' tende a ser o poder de consumo em meio à pobreza e, concomitantemente, um "modo de individualização e de integração subordinada” (Pinho, 2006, p. 180) -e que a condição dos trabalhadores negros no imediato pós-abolição corrobora com a pobreza necessária para o funcionamento desse sistema. Portanto, em consonância com as argumentações desses autores, é possível afirmar que o sistema capitalista foi implementado por meio de uma desigualdade intencional e que a mesma burguesia que o implementou segue desfrutando desses privilégios e alimentando as desigualdades para a manutenção desse sistema.

O subdesenvolvimento, advindo do imperialismo, tem como marca a subordinação a interesses que afetam a esfera econômica, política e cultural (etnocêntrica) do país explorado. Neste modelo, as economias periféricas terminam por transferir seus recursos para os centros e, no fim, “esse intercâmbio desigual gera impedimentos ao desenvolvimento" (Pinto, 2012, p. 352) destas, mantendo-as em subdesenvolvimento. Assim como Fernandes e Ianni, Pinto demonstra que a dependência da burguesia é ditada por dois fatores: o receio de ficar para trás na corrida capitalista e o verdadeiro pânico de uma revolução da classe proletária. Portanto, o estado de dependência da burguesia não é somente uma simples manutenção de privilégios, mas uma contra-revolução orquestrada que antecede as possibilidades de empoderamento do proletariado.

Dentre as artimanhas da burguesia, uma das que se destacam nas obras de Fernandes e Ianni é a universalização de interesses de classe. Reforçando essa ideia, Lazagna et al (2008) argumentam que a imposição da universalidade política do Estado-nação limita os indivíduos de uma sociedade e opera por uma lógica supraclassista e supra-identitária e "[...] quase sempre homogeneizadora, no sentido de garantir a unidade de uma maioria social 'instável' que legitime os interesses de gru- 
pos sociais em 'interesses nacionais' (Braga en Lazagna et al, 2008, p. 103). Essa universalização nada mais é do que uma forma de aprofundar a alienação à qual a classe proletária foi colocada, tratando interesses que só favorecem à burguesia como se fossem interesses nacionais. A expressão de tais interesses só reforça ainda mais as disparidades e faz com que a população mais afetada tome decisões cada vez menos lúcidas.

O antropólogo Osmundo Pinho argumenta que o consumo de bens e ideias de países imperialistas determina "o tom dos processos de desenvolvimento das sociedades periféricas" (Pinho, 2006, p. 180) -justificando, assim como Fernandes, que o consumismo em meio ao subdesenvolvimento se mostra a expressão máxima da modernidade. Diante dessa argumentação, é possível afirmar que a dependência da burguesia nacional em relação ao imperialismo; em meio à justa contradição entre a aspiração ao estilo de vida do capitalismo central e o eminente atraso de uma sociedade dependente e sem identidade própria, se mostra uma profunda e enraizada trava ao desenvolvimento econômico, pois, afinal: a burguesia nacional, mesmo expressando alguns escassos interesses no mercado nacional, determina limites bastante específicos ao desenvolvimento interno, que, subordinados a interesses imperialistas, continuarão fazendo com que nossa história siga alheia a um projeto de desenvolvimento nacional que realmente contemple o Brasil em sua diversidade.

\section{ConsideraÇões Finais}

Este trabalho teve como objetivo analisar, a partir da ótica marxista, os efeitos do racismo sobre o desenvolvimento econômico do Brasil. Sob a luz dos trabalhos de Florestan Fernandes e Octávio Ianni, a busca por essa compreensão nos levou a três fatores inerentes ao sistema capitalista: ausência de identidade, desenvolvimento desigual e dependência.

Na historiografia levantada pelos autores, tomando como marco a independência do Brasil e o consequente "atraso" em relação à corrida capitalista exacerbada pela segunda revolução industrial, o Brasil se destoa do "ritmo da história" e, por esse fato, vivemos a consequência disso como nação - pois, a partir daí, com os surtos de prosperidade, a contradição entre o escravizado e a mercadoria contribuiu para a estruturação do regime de classes como o temos hoje: essencialmente marcado pela cor da pele.

A partir das teses de Fernandes e Ianni, colocadas à luz dos artigos mais recentes, foi possível notar que, em nível estrutural, as críticas continuam muito próximas. O Brasil segue com o problema estrutural de classes, com uma burguesia que se vale do racismo -dentre outras formas de preconceito- para continuar promovendo o regime de classe que lhes favorece. No que tange as divergências entre os autores, pode-se dizer que elas ocorrem majoritariamente na abordagem usada para se falar do mesmo problema.

Portanto, é importante levar em conta a heterogeneidade existente dentro do próprio proletariado, ao ponto de elevar a compreensão de que as assimetrias estruturais se reproduzem dentro de sua própria estrutura e que essa consciência de classe não está livre de peças - ao ponto de que a consciência de classe pode se manifestar sob rótulos diferentes. O exemplo mais prático dessa afirmativa pode ser visto no racismo ou no machismo que seguem presentes em movimentos sociais que dizem lutar a favor de pessoas negras ou de mulheres.

Considerando que as próprias inovações tecnológicas já trabalham a favor do capitalista e que reduzem drasticamente as chances do proletariado se fortalecer por meio de sindicatos e prosperar (especificamente pelo fato de que, gradativamente, essas inovações expulsam o trabalhador dos 
meios de produção e de que isso tem se intensificado de forma ininterrupta), é de fundamental importância compreender quais outras razões mantêm o proletariado disperso. É possível começar citando o fato de que temos uma população que não se identifica como parte de um todo: a ausência de uma identidade explica não só a susceptibilidade da população em relação ao discurso de heróis de barro -normalmente europeizados, ou o mais próximo possível de tal- mas também a razão pela qual não desenvolvemos uma identidade própria. Considerando que o racismo do Brasil faz com que pessoas negras sejam invisíveis e não vistas como parte de um todo, faz-se explicado o fato de que lideranças ou mesmo o empoderamento da população negra na luta de classes sejam inviabilizados.

Diante disso, é de fundamental importância observar o contraste existente, entre pessoas negras e não negras, em suas relações sociais. Não se trata apenas de pensar na (necessária) inclusão da população negra, mas sim de promover melhores oportunidades para todos. Por essa razão, é de grande importância que essa densa barreira seja estrategicamente quebrada, de baixo para cima -mostrando que mesmo quem não sofre diretamente com esse paradigma é estrutural e indiretamente prejudicado, sem ao menos ter a capacidade de notar.

\section{REFERÊNCIAS}

Albernaz, R. e Azevêdo, A. (2011). Pluralização societária e os desafios à administração pública na América Latina. Sociedade e Estado, 26(2), 329-352. Dor: 10.1590/S0102-69922011000 200015

Appelbaum, N. (1999). Whitening the Region: Caucano Mediation and "Antioqueño Coionization” in Nineteenth-Century Coiombia. Hispanic American Historical Review, 79(4), 631-667. DOI: $10.1215 / 00182168-79.4 .631$

Bento, M. A. (1995). Mulher negra no mercado de trabalho. Revista Estudos Feministas, 3(2), 479-479.

Camargo, G. L. V. de. (2005). Esculturas públicas em Curitiba e a estética autoritária. Revista de Sociologia e Politica, 25, 63-82. DoI: 10.1590/S0104-44782005000200007

Carvalho Filho, J. L. (2016). Segregação espacial e segregação escolar: Notas para uma sociologia da distribuição espacial e social dos estabelecimentos de ensino. Mediações. Revista de Ciências Sociais, 21(2), 359-380. DOI: 10.5433/2176-6665.2016v21n2p359

Fernandes, F. (1964). A integração do negro na sociedade de classes. São Paulo: Universidade de São Paulo.

Fernandes, F. (1971). Brancos e negros em São Paulo. Ensaio sociológico sôbre aspectos da formação, manifestações atuais e efeitos do preconceito de côr na sociedade paulistana. São Paulo: Companhia Editora Nacional.

Fernandes, F. (1972). Sociedade de classes e subdesenvolvimento. Rio de Janeiro: Zahar.

Fernandes, F. (1973). Capitalismo dependente: E classes sociais na América latina. Rio de Janeiro: Zahar.

Fernandes, F. (1976). A revolução burguesa no Brasil: Ensaio de interpretação sociológica. Rio de Janeiro: Zahar.

Fernandes, F. (1981). O que é revolução. São Paulo-Brasil: Brasiliense.

Góis, J. B. (2008). Quando raça conta: Um estudo de diferenças entre mulheres brancas e negras no acesso e permanência no ensino superior. Revista Estudos Feministas, 16(3), 743-768. DoI: 10.1590/S0104-026X2008000300002 
Hoffman, K., e Centeno, M. A. (2006). Um continente entortado (América Latina). Tempo Social, 18(2), 11-46. DOI: 10.1590/S0103-20702006000200002

Ianni, O. (1966). Raças e classes sociais no Brasil. Rio de Janeiro: Civilizaçao Brasileira. Ianni, O. (1994). A idéia de Brasil moderno. São Paulo: Brasiliense.

Ianni, O. (2000). Tendências do pensamento brasileiro. Tempo Social, 12(2), 55-74. DoI: 10.1590 /S0103-20702000000200006

Jacobson, M. F. (1999). Whiteness of a different color: European immigrants and the alchemy of race. Harvard: Harvard University Press.

Lazagna, Â., Löwy, M., e Cahen, M. (2008). Nacionalismos e internacionalismo: Um debate entre Michael Löwy e Michel Cahen. Revista de Sociologia e Política, 16(31), 101-119. DOI: 10.1590/S0104-44782008000200009

Marinho, T. A. (2017). Territorialidade e cultura entre os Kalunga: Para além do culturalismo. Caderno CRH, 30(80), 353-370. DoI: 10.1590/s0103-49792017000200009

Passos, J. C., e Nogueira, J. C. (2014). Movimento negro, ação política e as transformações sociais no Brasil contemporâneo. Política E Sociedade, 13(28), 105-124. DoI: 10.5007/2175$7984.2014 \mathrm{v} 13 \mathrm{n} 28 \mathrm{p} 105$

Pinho, O. A. (2006). A vida em que vivemos: Raça, gênero e modernidade em São Gonçalo. Revista Estudos Feministas, 14, 169-198. DoI: 10.1590/S0104-026X2006000100010

Pinto, S. (2012). O pensamento social e político Latino-Americano: Etapas de seu desenvolvimento. Sociedade e Estado, 27(2), 337-359.

Quijano, A. (2005). Colonialidade do poder, eurocentrismo e América Latina. En A colonialidade do saber: Eurocentrismo e ciências sociais. Perspectivas latino-americanas (pp. 117-142). Buenos Aires: Consejo Latinoamericano de Ciencias Sociales.

Salata, A. (2018). Ensino superior no Brasil das últimas décadas: Redução nas desigualdades de acesso? Tempo Social, 30(2), 219-253. DOI: 10.11606/0103-2070.ts.2018.125482

Sales Jr., R. (2006a). Democracia racial: O não-dito racista. Tempo Social, 18(2), 229-258. DoI: $10.1590 / \mathrm{S} 0103-20702006000200012$

Sales Jr., R. (2006b). Raça e justiça: O mito da democracia racial e racismo institucional no fluxo de justiça (Tese de doutorado). Universidade Federal de Pernambuco, Recife.

Sampaio Junior, P. A. (1999). Entre a nação e a barbárie: Os dilemas do capitalismo dependente em Caio prado, Florestan Fernandes e Celso Furtado. Petrópolis: Vozes.

Wacquant, L. (2004). Que é gueto? Construindo um conceito sociológico. Revista de Sociologia e Política, 23, 155-164.

Wallerstein, I. (1979). El moderno sistema mundial I: la agricultura capitalista y los orígenes de la economía-mundo europea en el siglo ХVI. Madrid: Siglo XXI de España.

Wallerstein, I. (1984). El moderno sistema mundial: I, La agricultura capitalista y los orígenes de la economía-mundo europea en el siglo XVI. II, El mercantilismo y la consolidación de la economía-mundo europea, 1600-1750. Madrid: Siglo XXI.

Wallerstein, I. (1998). El moderno sistema mundial III: La segunda era de la gran expansión de la economía mundo-capitalista, 1730-1850. Madrid: Siglo XXI.

Willems, E. (2009). O problema rural brasileiro do ponto de vista antropológico. Tempo Social, 21, 187-210. DoI: 10.1590/S0103-20702009000100011 